\title{
Seasonal and diurnal performance of daily forecasts with WRF V3.8.1 over the United Arab Emirates
}

\author{
Oliver Branch $^{1}$, Thomas Schwitalla ${ }^{1}$, Marouane Temimi $^{2}$, Ricardo Fonseca ${ }^{3}$, Narendra Nelli ${ }^{3}$, Michael Weston ${ }^{3}$, \\ Josipa Milovac ${ }^{4}$, and Volker Wulfmeyer ${ }^{1}$ \\ ${ }^{1}$ Institute of Physics and Meteorology, University of Hohenheim, 70593 Stuttgart, Germany \\ ${ }^{2}$ Department of Civil, Environmental, and Ocean Engineering (CEOE), Stevens Institute of Technology, New Jersey, USA \\ ${ }^{3}$ Khalifa University of Science and Technology, Abu Dhabi, United Arab Emirates \\ ${ }^{4}$ Meteorology Group, Instituto de Física de Cantabria, CSIC-University of Cantabria, Santander, Spain
}

Correspondence: Oliver Branch (oliver_branch@uni-hohenheim.de)

Received: 19 June 2020 - Discussion started: 1 September 2020

Revised: 10 February 2021 - Accepted: 11 February 2021 - Published: 19 March 2021

\begin{abstract}
Effective numerical weather forecasting is vital in arid regions like the United Arab Emirates (UAE) where extreme events like heat waves, flash floods, and dust storms are severe. Hence, accurate forecasting of quantities like surface temperatures and humidity is very important. To date, there have been few seasonal-to-annual scale verification studies with WRF at high spatial and temporal resolution.

This study employs a convection-permitting scale $(2.7 \mathrm{~km}$ grid scale) simulation with WRF with Noah-MP, in daily forecast mode, from 1 January to 30 November 2015. WRF was verified using measurements of $2 \mathrm{~m}$ air temperature $\left(T_{2} \mathrm{~m}\right), 2 \mathrm{~m}$ dew point $\left(\mathrm{TD}_{2} \mathrm{~m}\right)$, and $10 \mathrm{~m}$ wind speed $\left(\mathrm{UV}_{10 \mathrm{~m}}\right)$ from 48 UAE WMO-compliant surface weather stations. Analysis was made of seasonal and diurnal performance within the desert, marine, and mountain regions of the UAE.

Results show that WRF represents temperature $\left(T_{2 \mathrm{~m}}\right)$ quite adequately during the daytime with biases $\leq+1^{\circ} \mathrm{C}$. There is, however, a nocturnal cold bias $\left(-1\right.$ to $\left.-4{ }^{\circ} \mathrm{C}\right)$, which increases during hotter months in the desert and mountain regions. The marine region has the smallest $T_{2 \mathrm{~m}}$ biases $\left(\leq-0.75^{\circ} \mathrm{C}\right)$. WRF performs well regarding $\mathrm{TD}_{2} \mathrm{~m}$, with mean biases mostly $\leq 1^{\circ} \mathrm{C}$. $\mathrm{TD}_{2 \mathrm{~m}}$ over the marine region is overestimated, though $\left(0.75-1^{\circ} \mathrm{C}\right)$, and nocturnal mountain $\mathrm{TD}_{2 \mathrm{~m}}$ is underestimated $\left(\sim-2^{\circ} \mathrm{C}\right)$. $\mathrm{UV}_{10 \mathrm{~m}}$ performance on land still needs improvement, and biases can occasionally be large $\left(1-2 \mathrm{~m} \mathrm{~s}^{-1}\right)$. This performance tends to worsen during the hot months, particularly inland with peak biases reaching $\sim 3 \mathrm{~m} \mathrm{~s}^{-1}$. $\mathrm{UV}_{10 \mathrm{~m}}$ is better simulated in the marine region (bias $\leq 1 \mathrm{~m} \mathrm{~s}^{-1}$ ). There is an apparent relationship between
\end{abstract}

$T_{2 \mathrm{~m}}$ bias and $\mathrm{UV}_{10 \mathrm{~m}}$ bias, which may indicate issues in simulation of the daytime sea breeze. $\mathrm{TD}_{2} \mathrm{~m}$ biases tend to be more independent.

Studies such as these are vital for accurate assessment of WRF nowcasting performance and to identify model deficiencies. By combining sensitivity tests, process, and observational studies with seasonal verification, we can further improve forecasting systems for the UAE.

\section{Introduction}

In a changing climate, effective numerical weather forecasting is vital in arid regions like the United Arab Emirates (UAE), to predict low-visibility events like fog and dust (e.g., Aldababseh and Temimi, 2017; Chaouch et al., 2017; Karagulian et al., 2019), and extreme events relating to storms and flash floods (Chowdhury et al., 2016; Wehbe et al., 2019), high temperatures, and droughts. These extreme events are expected to become more prevalent under a changing climate (Feng et al., 2014; Zhao et al., 2020). In fact, climate projections suggest that arid and semiarid regions are likely to expand in area along with rising temperatures (Huang et al., 2017; Lelieveld et al., 2016; Lu et al., 2007). Hence, it is vital that regional weather forecasting and climate simulations with regional climate models (RCMs) correctly simulate important quantities which characterize extreme events, especially surface temperatures, humidity, winds, and precipitation. 
The model chain and configuration used in any simulation can heavily influence the results of such forecasts. Important factors include but are not limited to the RCM type (e.g., Coppola et al., 2020), general circulation model (GCM) dataset for boundary forcing (Gutowski et al., 2016; Jacob et al., 2020), horizontal and vertical grid resolutions (e.g., Schwitalla et al., 2017), physics and dynamics schemes (e.g., Chaouch et al., 2017; Schwitalla et al., 2020), and soil-landuse-terrain static data, as well as internal model parameter sets for important land surface processes (e.g., Weston et al., 2019).

The Weather Research and Forecasting (WRF) model (Powers et al., 2017; Skamarock et al., 2008) has been used in arid regions for various forecasting and verification purposes (e.g., Branch et al., 2014; Fonseca et al., 2020; Schwitalla et al., 2020; Valappil et al., 2020; Wehbe et al., 2019) and process studies (Becker et al., 2013; Branch and Wulfmeyer, 2019; Karagulian et al., 2019; Nelli et al., 2020a; Wulfmeyer et al., 2014). Currently, there have been few annual-scale verification studies employing the WRF model on a NWP daily forecasting mode at such high spatiotemporal resolution (e.g., $\mathrm{d} x<2-3 \mathrm{~km}$ ). Horizontal grid scale is significant because simulations employing convection-permitting (CP) grid spacing ( $\mathrm{d} x \sim<4 \mathrm{~km}$ ) are known to outperform those at coarser resolutions, particularly in terms of clouds and precipitation - not least because they do not require a convection parameterization (Bauer et al., 2015, 2011; Prein et al., 2015; Schwitalla et al., 2011, 2017; Sørland et al., 2018). Furthermore, it is known that land use, soil texture, and terrain interact with planetary boundary layer (PBL) processes in complex feedbacks (e.g., Anthes, 1984; Mahmood et al., 2014; Pielkel and Avissar, 1990; Smith et al., 2014) with a strong level of land-atmosphere (LA) coupling thought to exist in this region (Koster et al., 2006). Representation of landscape structure and the associated LA feedbacks should therefore be significantly improved when using finer grid resolution. In terms of timescale, seasonal-to-annual simulations are costly but provide a sufficient time series for robust statistical comparison with observations over different seasons.

This study employs a configuration of WRF, coupled with the NOAH-MP "multi-physics" land surface model (LSM), with modular parameterization options (Niu et al., 2011). In contrast to typical climate mode simulations, WRF is run here in a numerical weather prediction (NWP), or daily forecasting, mode in order to keep conditions inside the domain closer to that of the forcing data (see Sect. 2.3.3, for further details). We also apply high-quality and high-resolution boundary forcing data, improved static data for land use, soils, terrain, high-frequency aerosol optical depth, and sea surface temperature. This WRF configuration was employed and verified by Schwitalla et al. (2020) within a one-day case study of a physics ensemble.

Our main objective is to assess the seasonal and diurnal performance of WRF - both qualitatively and quantitatively - in reproducing surface air temperature, dew point, and wind data from 48 WMO-compliant surface weather stations distributed over the UAE.

Another objective is to assess the model performance in different areas of the UAE - which was split broadly into three environments: (1) northern coastline and islands, (2) inland lowland desert areas, and (3) the Al Hajar Mountains in the east. The aim is to investigate differences in performance due to expected differences in climate regimes within these zones, and their respective surface and landscape characteristics and how they are dealt with by WRF with NoahMP. Factors include, amongst others, the influence of sea surface temperatures in the warm and shallow Arabian Gulf (Al Azhar et al., 2016), representation of albedo (Fonseca et al., 2020) and roughness length parameters (Weston et al., 2019), and limitations in simulations over orography, particularly with respect to the wind field (e.g., Warrach-Sagi et al., 2013). The Al Hajar Mountains have a complex climate with regular coastal fog and convective events (e.g., Branch et al., 2020a). Therefore, splitting verification into the above zones (in which the stations are quite evenly distributed, with 17 , 15 , and 16 stations, respectively) can yield further insights into model performance and climate characteristics in different environments.

Through ambitious simulations and robust verification, we can gain valuable insights into the regional climate and model performance and take a step towards more skilful weather forecasting with WRF with Noah-MP in the UAE.

The structure of this work is as follows: we start with our materials and methods (Sect. 2), showing maps of the study area and model domain (Sect. 2.1); a description of the regional climate (Sect. 2.2); the model chain, configuration, and simulation method (Sect. 2.3); verification dataset (Sect. 2.4); and verification methods (Sect. 2.5). Then follows a results and discussion section (Sect. 3) and finally a summary and outlook (Sect. 4).

\section{Materials and methods}

\subsection{Study area and model domain}

The region under investigation is the United Arab Emirates (UAE) located between 22.61-26.43 ${ }^{\circ} \mathrm{N}$ and $51.54-56.55^{\circ} \mathrm{E}$ in the far northeast of the Arabian Peninsula (see Fig. 1a), with the 48 surface verification stations being spread out across the country. The model domain is shown in Fig. 1b and covers a much larger area, (a) to be sure of excluding the area with the strong effects of the boundary forcing (i.e., relaxation zone) from the analysis, and (b) to incorporate the large-scale synoptic weather situation. The model uses a regular latitude-longitude grid and has corner grid cells located at $14.775^{\circ} \mathrm{N}, 32.225^{\circ} \mathrm{N}, 43.275^{\circ} \mathrm{E}$, and $65.725^{\circ} \mathrm{E}$. 

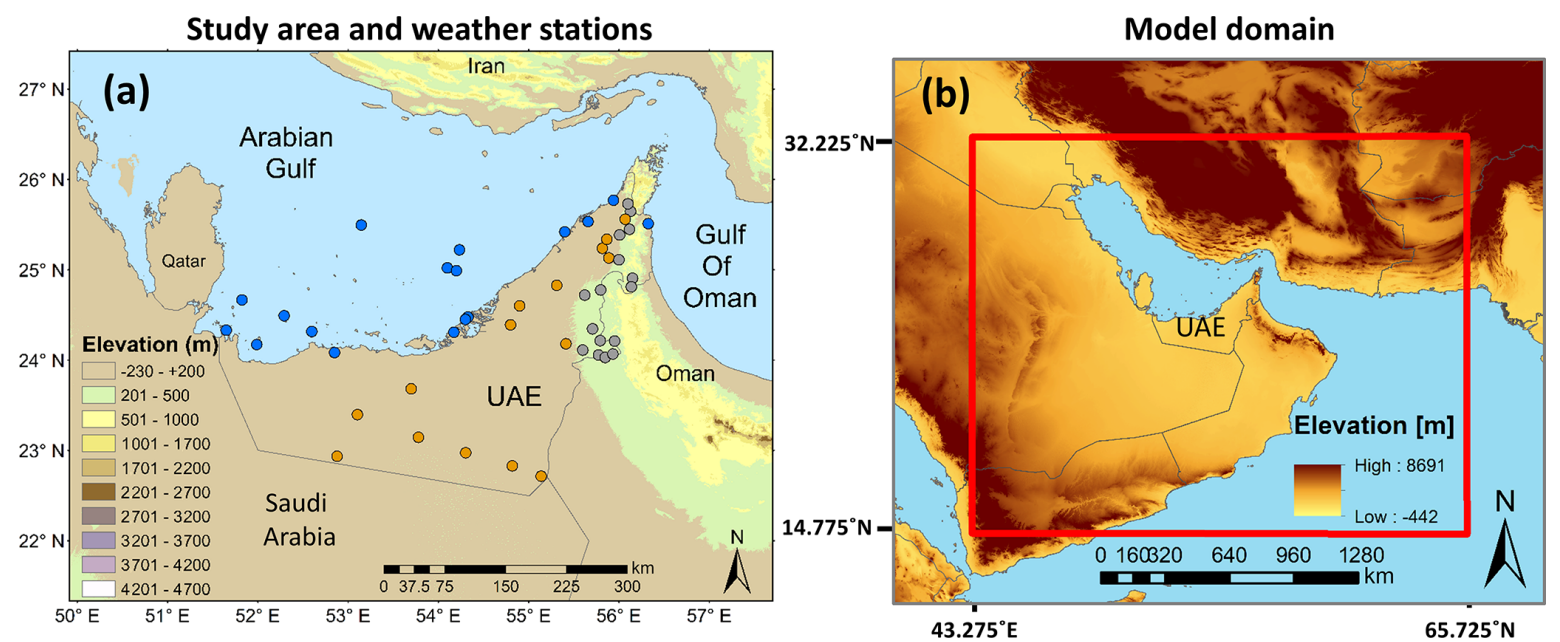

Figure 1. Panel (a) is a close-up of the study area overlaid with classified topography and 48 UAE surface weather stations used for verification of WRF. Weather data were provided by the National Centre for Meteorology (NCM) in the UAE. The weather stations were grouped into geophysical regions for statistical analysis. The 17 blue dots indicate coastal and marine stations (criteria - on islands or within $5 \mathrm{~km}$ from coastline). The 16 grey dots are mountain stations (criteria - any station $\geq 200 \mathrm{~m}$ a.s.l. and $>5 \mathrm{~km}$ from coast). The 15 orange dots are inland desert stations (criteria - all remaining stations). Panel (b) is the $900 \times 700$ grid cell model domain $(\Delta x 2.7 \mathrm{~km}, 2430 \times 1890 \mathrm{~km})$. The four corner model grid cells are located at $14.775^{\circ} \mathrm{N}, 32.225^{\circ} \mathrm{N}, 43.275^{\circ} \mathrm{E}$, and $65.725^{\circ} \mathrm{E}$.

\subsection{Regional climate}

\subsubsection{Synoptic climate}

Weather in the wider region is generally controlled by four predominant patterns, including troughs originating from the Atlantic and Mediterranean Sea in winter, locally forced convective storms over the UAE and Oman Al Hajar Mountains in summer, and the southerly summer monsoon and cyclones from the Arabian Sea during June and October (Bruintjes and Yates, 2003; Steinhoff et al., 2018). These phenomena are represented in large-scale seasonal climatologies (1979-2014 - 08:00 UTC) in Figs. 2 and 3 (right-hand panels). To represent the climate, we have used geopotential height at $500 \mathrm{hPa}$, wind velocity at $850 \mathrm{hPa}$, and mean sea level pressure. Note that winter is represented exclusively by the months of January and February, because these are the months used for our winter analysis during 2015 - for reasons of temporal continuity. In the climatology, we can clearly see a typical winter January-February (JF) low centered over Turkey and Iraq and a trough extending down toward the Arabian Peninsula. During summer, in June, July, and August (JJA), we observe much higher temperatures further south, with a heat low centered over Iran and the UAE. The other two seasons are transitional periods.

\subsubsection{UAE climate}

The UAE climate is generally characterized by scarce precipitation and high temperatures. However, annual cycles do exist with maxima of precipitation and minima of temperatures in winter and the converse in summer. Annual UAE pre- cipitation is between $20 \mathrm{~mm}$ in the drier west to $130 \mathrm{~mm}$ in the higher Al Hajar Mountains of the east, mainly produced in the winter-spring time period (Sherif et al., 2014). During summer, subtropical subsidence leads to a strong reduction of precipitation and higher temperatures, and consequently summer precipitation represents only around $20 \%$ of the annual amounts. However, upper-level disturbances from the southern monsoon flows can still transport moisture towards the Arabian Peninsula and the UAE (Böer, 1997; Schwitalla et al., 2020), and convection is initiated sporadically over the mountains of Oman and the UAE in summertime (Branch et al., 2020a).

The neighboring Arabian Gulf to the north of the UAE also plays a strong role in regional weather conditions. The prevailing winds from the Arabian Gulf are westerly or northwesterly between January and May, but these change to northwesterly and then northerly directions from June to November. In the Arabian Gulf, which is relatively shallow (maximum depth $\sim 90 \mathrm{~m}$ ), particularly close to the UAE coast, the sea surface can heat rapidly, with temperatures often exceeding $30^{\circ} \mathrm{C}$ ( $\mathrm{Al}$ Azhar et al., 2016). Prevailing winds are augmented by strong sea and land breezes, which develop due to land-sea temperature gradients. Daytime sea breezes can penetrate up to $50 \mathrm{~km}$ inland (Eager et al., 2008).

\subsection{Model chain and simulation method}

\subsubsection{Model chain and physics}

The model chain is based on the Weather Research and Forecasting model version 3.8.1 using the Advanced Research WRF (ARW) core, which solves the Euler equations on a dis- 


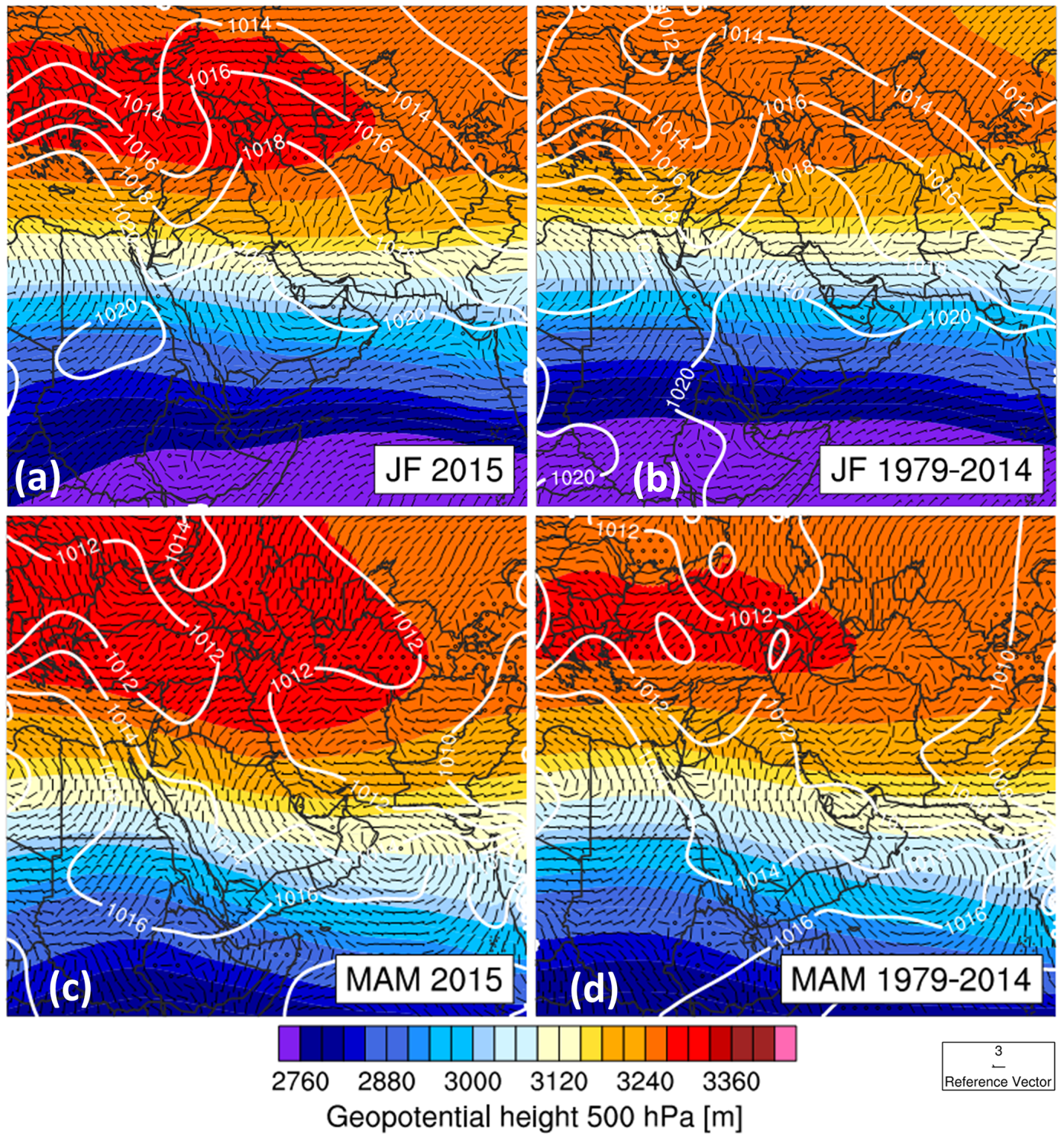

Figure 2. Comparison of the 2015 (a) winter (January-February, JF) and (c) spring (March-May, MAM) large-scale fields at 08:00 UTC. Panels (b) and (d) are an equivalent 36-year climatology between 1979 and 2014. Variables shown are geopotential height at 500 hPa (m; shading), wind velocity at $850 \mathrm{hPa}\left(\mathrm{m} \mathrm{s}^{-1}\right.$; see reference vector at bottom right), and mean sea level pressure (hPa; white contours). Data are taken from the ECMWF ERA5 reanalysis dataset.

cretized horizontal grid, with a terrain-following vertical coordinate system. The domain size and grid spacing matches that of a previous simulation by Schwitalla et al. (2020) and is comprised of a regular latitude-longitude grid with 900 by 700 cells horizontally (see Fig. 1b). In line with our previous statements on $\mathrm{CP}$ scale we selected a grid increment of $0.025^{\circ}(\mathrm{d} x \sim 2779 \mathrm{~m})$, with no parameterization of deep convection. It was important to extend the domain enough to incorporate influential synoptic conditions upstream to the north, east, and southeast. Hence, our grid covers a region of approximately $2500 \mathrm{~km} \times 1945 \mathrm{~km}$ extending up to Iraq in the north, down to the south of Yemen, and well into Pak- istan in the east. Care was taken, for reasons of model stability, that domain boundaries did not bisect very large peaks, especially in the complex terrain of Iran. Vertically, $100 \mathrm{lev}$ els were used, adjusted so that at least 25 levels were present in the lower $2000 \mathrm{~m}$ - to maximize resolution of the strong moisture gradients in the boundary layer and lower troposphere.

WRF was coupled with the NOAH-MP LSM (Niu, 2011) to simulate land-surface processes and land-atmosphere feedbacks. NOAH-MP provides a separate vegetation canopy defined by a canopy top and ground layer including a modified energy balance closure approach. It offers a tile approach 


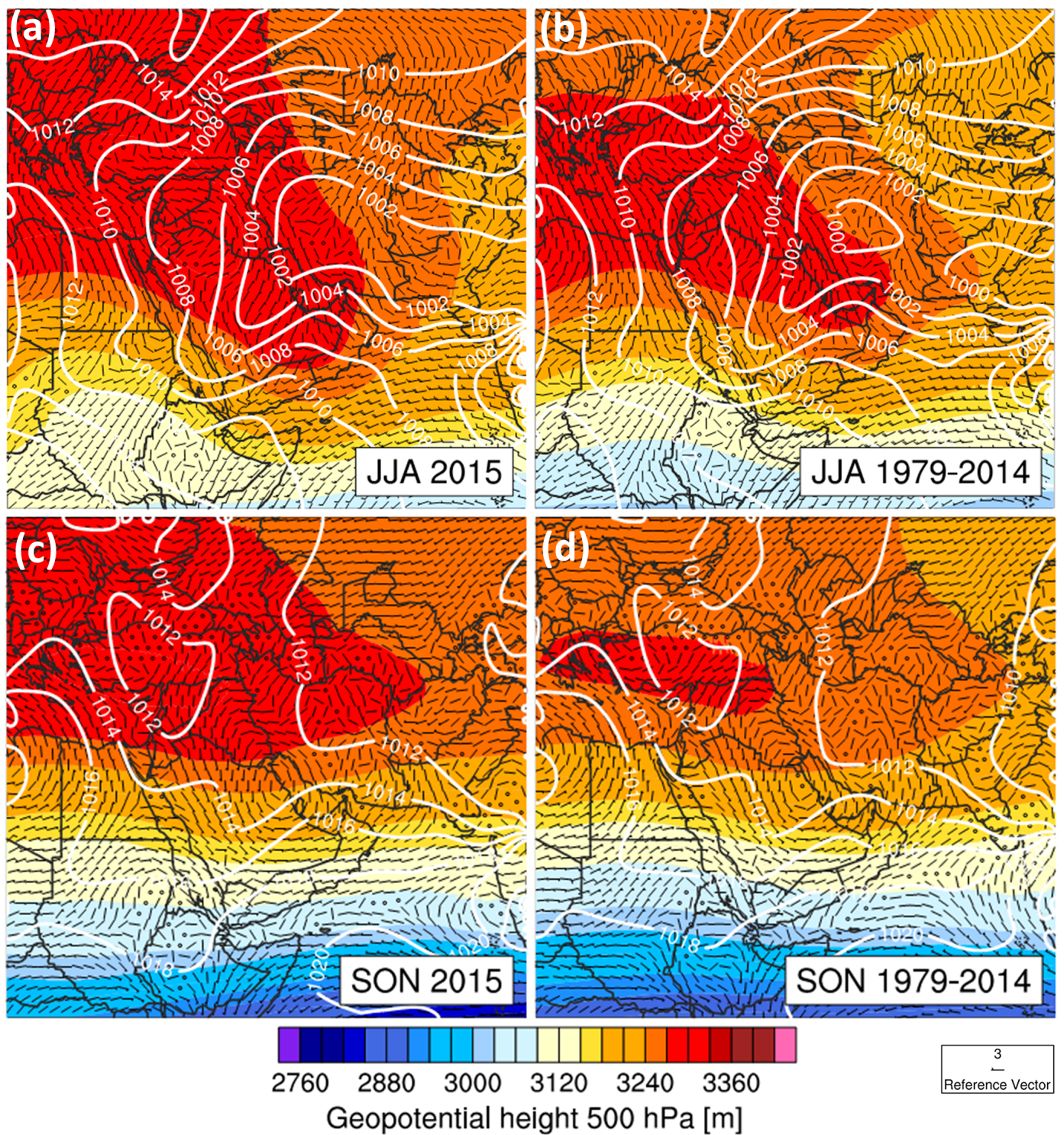

Figure 3. As for Fig. 2 but for summer and autumn: June-August (a, b) and September-November (c, d). Data were also taken from the ECMWF ERA5 reanalysis dataset.

where the net longwave radiation and turbulent fluxes are calculated separately for bare soil and the canopy layer. The calculated fluxes over vegetated grid cells are then bulked as a weighted sum of bare soil and canopy fluxes. Furthermore, NOAH-MP is partially modular in structure, providing a suite of optional schemes for several processes, such as radiation budget calculation, stomatal resistance, snow albedo, and others. The same configuration of Milovac et al. (2016) was used for all NOAH-MP options.

Other physics schemes included were the Rapid Radiative Transfer Model (RRTMG) for long- and shortwave radiation transfer (Iacono et al., 2008; Mlawer et al., 1997), the Thompson-Eidhammer microphysics scheme (Thompson and Eidhammer, 2014) (although without the aerosol- aware component activated), the Mellor-Yamada 2.5 Level scheme (MYNN) for the atmospheric surface layer, and the MYNN 2.5 level TKE scheme for the boundary layer (Nakanishi and Niino, 2006) (See Table 1 for a synopsis of physics schemes and their associated references).

\subsubsection{Initialization and forcing data}

\section{Initial and lateral boundary conditions}

These were retrieved from the European Centre for MediumRange Weather Forecasts (ECMWF) Integrated Forecasting System (IFS), in the form of 6-hourly operational analysis data on the 41r1 cycle, on model levels. The horizontal grid increment is $0.125^{\circ}(\sim 12 \mathrm{~km})$ with 137 vertical levels up to 
Table 1. Selected physics schemes in WRF for sub-grid processes.

\begin{tabular}{lll}
\hline Physics type & Scheme/option & Reference \\
\hline Land surface scheme & NOAH-MP & Niu et al. (2011) \\
Atmospheric surface layer & MYNN & Nakanishi and Niino (2006) \\
Atmospheric boundary layer & MYNN 2.5 level TKE & Nakanishi and Niino (2006) \\
SW radiation & RRTMG & Mlawer et al. (1997) \\
LW radiation & RRTMG & Iacono et al. (2008) \\
Microphysics & Thompson-Eidhammer & Thompson and Eidhammer (2014) \\
\hline
\end{tabular}

$0.01 \mathrm{hPa}$. Soil moisture and soil temperatures are also provided by this model, which assimilates satellite soil moisture data (Albergel et al., 2012) into its coupled Hydrology-Tiled ECMWF Scheme for Surface Exchange over Land (HTESSEL) model (Balsamo et al., 2009).

\section{Sea surface temperatures (SSTs)}

These data were retrieved from the OSTIA project (Donlon et al., 2012) - the data have a $1 / 20^{\circ}$ horizontal grid spacing at a 12-hourly frequency at 00:00 and 12:00 UTC. These data are particularly important in coastal regions like the UAE.

\section{Aerosol optical depth (AOD) data}

These data were retrieved from the ECMWF Monitoring Atmospheric Composition and Climate (MACC) reanalysis (Inness et al., 2013), which interacts with the shortwave radiation scheme to modify radiative transfer and diabatic heating - data have a $\sim 80 \mathrm{~km}$ horizontal grid spacing and a 6-hourly frequency starting from 00:00 UTC.

\section{Soil texture data}

These data are an update from the default Food and Agriculture Organization (FAO) dataset. The new data are based on the Harmonized World Soil Database (HWSD) v 1.2 at 30 arcsec grid spacing, where all the mapping units are reclassified into 12 soil and 4 non-soil types following the United States Department of Agriculture (USDA) soil classification system, as in the WRF model. For access to the data and more details see Milovac et al. (2018). The WRF default soil texture map based on the FAO data was used for the bottom soil layer.

\section{Land use data}

These data were provided as a combination of a highresolution dataset for the Emirates of Abu Dhabi and Dubai, provided by the National Center for Meteorology (NCM), and the International Geosphere-Biosphere Programme (IGBP) Moderate Resolution Infrared Spectroradiometer (MODIS) 20-class land use dataset, included within the WRF package (Fig. 4). The Abu Dhabi dataset contained some classes which differed from MODIS IGBP, and these were first reclassified in a logical manner before overwriting the MODIS dataset within the UAE (see Schwitalla et al., 2020 for further details of this process).

\section{Terrain data}

Here, we used the Global Multi-resolution Terrain Elevation Data (GMTED) 2010 static dataset (Danielson and Gesch, 2011)

\subsubsection{Simulation method}

The objective of this study was to run a series of daily forecasts with WRF for the period 1 January to 30 November 2015, with a discarded 1-month spin-up run from 1 December 2014. Note that December 2014 was not used for verification (observation data were in any case not available at that time; see Sect. 2.4). It also makes sense not to analyze a winter season split over 2 years.

The intention of carrying out such a long sequence was to produce a long enough dataset to provide sufficient data points for robust statistical analysis. Forecasts were carried out in NWP mode, i.e., with daily cold starts - as opposed to a "climate" mode, which has a single cold start at the outset. In NWP mode, a cold start was initiated each day at 18:00 UTC (22:00 LT) and run for 30 h, i.e., $6+24$ until 00:00 UTC the next day. The first $6 \mathrm{~h}$ of each forecast (18:00 to 00:00 UTC) were then discarded from the analysis. The $6 \mathrm{~h}$ allows time for the atmosphere to spin up after each cold start - in particular for the residual boundary layer to develop and dissipate before the convective boundary layer starts to develop after sunrise $(\sim 06: 00 \mathrm{LT})$, and for potential cloud development. Other UAE forecasting studies have also suggested that $5-6 \mathrm{~h}$ is an appropriate period for model convergence in the UAE region (Chaouch et al., 2017; Weston et al., 2019). After discarding the first $6 \mathrm{~h}$, a forecast remains for analysis spanning the $24 \mathrm{~h}$ of each day between 00:00 and 23:00 UTC (04:00 to 02:00 LT). See Table 2 for a summary of the simulation method.

By reinitializing the 3D state within the domain itself (as opposed to simply inputting lateral boundary conditions), we ensure the atmospheric state is closer to the forecast provided by ECMWF than would be the case in typical climate mode simulations. In climate mode, which is driven only at the 


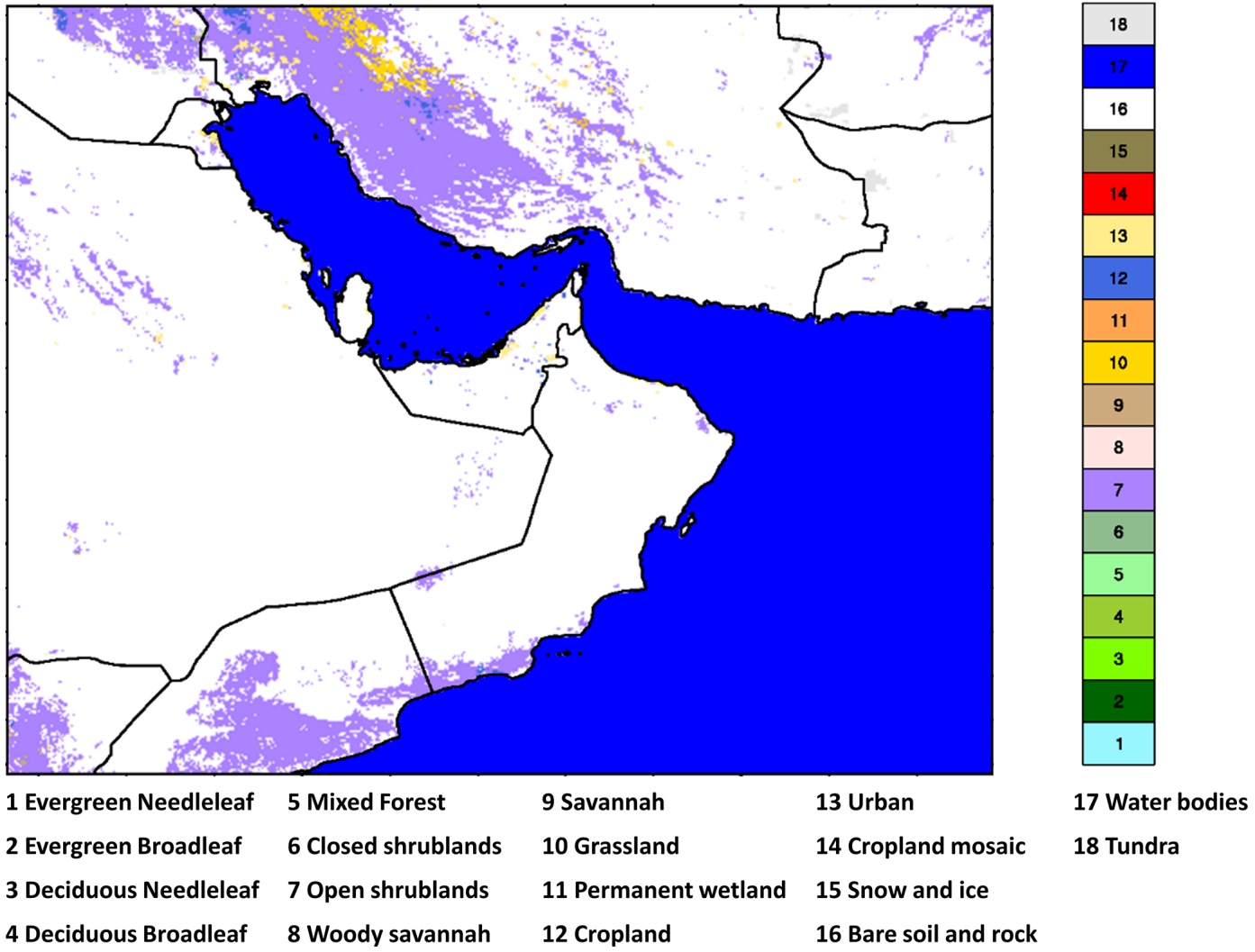

Figure 4. Map of whole model domain with the land cover dataset used in the simulation. It is a composite of the standard 30 arcsec $(\sim 1 \mathrm{~km})$ IGBP 21-class MODIS dataset included as standard with WRF, with two local datasets superimposed: Abu Dhabi and Dubai Emirates, obtained respectively from the Environment Agency of Abu Dhabi (EAD) and the International Center for Biosaline Agriculture (ICBA) in Dubai. The local datasets were first reclassified in a logical manner into MODIS categories. 18 classes are shown here. There is a reduction in resolution due to the grid increment of $2.7 \mathrm{~km}$.

boundaries, the WRF simulations may diverge more strongly, particularly toward the center of the large domain where the study area lies, unless some form of interior nudging were implemented (e.g., Lo et al., 2008).

An exception to the daily reinitialization of state variables was made with the soil moisture field, whose state was intentionally maintained from one successive day to the next, by overwriting the soil moisture state from 18:00 to the next day at 18:00, when the forecast is restarted. The intention is to reduce physical inconsistencies between the soil moisture forecast in the driving GCM model and that of WRF with Noah-MP. Intuitively that may not seem a large issue given the aridity of the UAE. However, it becomes significant when convective precipitation occurs in WRF, and soils are wetted. Such convective events and flash floods are common in the UAE and Oman, particularly from May to September in the mountains, including during 2015 (Branch et al., 2020a; Schwitalla et al., 2020; Wehbe et al., 2019). Hence, the NWP method is a worthwhile method of improving physical consistency. To summarize the NWP configuration: the soil moisture is overwritten at 18:00 UTC from each consecutive day to the next, for the start of each new forecast. The lateral boundary conditions are as for a climate mode run, i.e., input every $6 \mathrm{~h}$ from the forcing data. The atmospheric state within the domain boundaries is reinitialized each day at 18:00 UTC.

\subsection{Datasets for verification}

Hourly verification data come from 48 surface weather stations throughout the UAE (Fig. 1a and Appendix Table A1) and is quality checked and made available by the National Center for Meteorology (NCM) in Abu Dhabi, UAE. Fields available include air temperature at $2 \mathrm{~m}\left(T_{2 \mathrm{~m}}\right)$, dew point at $2 \mathrm{~m}\left(\mathrm{TD}_{2} \mathrm{~m}\right)$ representing humidity, and wind speed at $10 \mathrm{~m}\left(\mathrm{UV}_{10 \mathrm{~m}}\right)$. Data cover the entire period of 1 January30 November 2015 . Unfortunately, quality checked observation data for December 2014 were not available and so in the interest of preserving contiguous seasons, the month of December 2015 was omitted from the winter statistics.

\subsection{Verification method}

An aim of the study is to assess WRF's performance on several timescales: annually (January-November), seasonally, 
Table 2. Summary of main aspects of simulation.

\begin{tabular}{lll}
\hline Total duration of daily forecasts & 1 December 2014 to 30 November 2015 & \\
Period of analysis & 1 January to 30 November 2015 & \\
WRF output frequency & 1-hourly & 48 surface weather stations \\
Verification data frequency & 1-hourly & ECMWF operational analysis $\left(0.12^{\circ}\right)$ \\
Boundary forcing frequency & 6-hourly & OSTIA data \\
SST forcing frequency & 6-hourly & ECMWF MACC reanalysis \\
AOD forcing frequency & 6-hourly & MODIS IGBP - 21 classes \\
Land use data & Static & Modified HWSD (Milovac et al., 2018) \\
Soil texture & Static & GMTED 2010 \\
Terrain & Static & \\
Cold start initialization & $18: 00$ UTC daily & \\
Fields for reinitialization & All except soil moisture - all four soil levels & \\
Forecast length & $30 \mathrm{~h}$ (first $6 \mathrm{~h}$ discarded) & \\
Forecast analysis & $24 \mathrm{~h}-00: 00$ to 23:00 UTC & \\
Model integration time step & $15 \mathrm{~s}$ & \\
\hline
\end{tabular}

daytime and nighttime periods, and hourly. Another aim is to assess performance within different regions of the UAE. The exclusive assessment of overall forecast means over the UAE may be valuable but could obscure variability within the different regions, such as the capturing of high daytime temperatures in the inland deserts, or cooler and windier coastal conditions.

Accordingly, the dataset was split temporally and spatially, as follows.

\subsubsection{Temporal analysis}

\section{Yearly analysis}

Here, all time steps were analyzed from 1 January to 30 November (hourly interval).

\section{Seasonal analysis}

Here, we present the most extreme seasons in terms of air temperatures - the (coolest) winter period of 1 January28 February 2015 and the (warmest) summer period of 1 June to 31 August 2015.

\section{Daytime and nighttime periods}

For daylight hours we used all hours between 02:00 and 13:00 UTC (06:00-17:00 LT) - and for nighttime, 14:00 to 01:00 UTC (18:00-05:00 LT). These hours were selected based on the range of UAE sunrise and sunset which range between $\sim$ 05:30 and 07:00 and between $\sim$ 17:00 and 18:50 LT respectively. The intention of separating day and night hours in this way is to examine performance during the nocturnal stable and daytime convective boundary layers. Indeed, several simulations in arid regions have demonstrated nocturnal cold biases and an overestimation of daytime wind speeds (Branch et al., 2014; Schwitalla et al., 2020; Weston et al., 2019).

\section{Regional analysis}

We split the 48 UAE weather stations into three regions marine, mountain, and desert - based on surface geophysical characteristics and proximity to water bodies (See Fig. 1a). Accordingly, the following criteria were used for grouping the weather stations into regions:

- marine - located on islands or $\leq 5 \mathrm{~km}$ inland from the UAE coast (17 stations);

- mountain - located in the Al Hajar Mountain area and $\geq 200 \mathrm{~m}$ a.s.l. (16 stations);

- desert - located $>5 \mathrm{~km}$ distance inland and $<200$ m a.s.l. (15 stations).

The only exception made to this classification was for a single station located at $204 \mathrm{~m}$ near the sand dunes of Liwa, in the south of the Abu Dhabi emirate. Although the station is quite high, it is remote from the Al Hajar Range and was deemed more suitable for a desert classification. Details on altitude of the regional station groups can be found in Table 3, and a list of individual stations in the Appendix. The desert region is characterized by barren or sparsely vegetated soils (as is most of the UAE), high surface temperatures, and rapid nighttime cooling due to radiative losses associated with a dry atmosphere. The Al Hajar mountain region is arid and has generally rocky bare slopes and lower albedo (e.g., Moody et al., 2005), with gravel plains running along the west side (Sherif et al., 2014).

One can assume some similarity between these regions, particularly when the synoptic situation is relatively homogeneous over scales larger than the study area. Nevertheless, given the large number of stations and length of time series, if regional differences do exist then they should be evident. 
Table 3. Number and altitude statistics for the regions - marine, desert, and mountain.

\begin{tabular}{lrrrr}
\hline Region & $\begin{array}{r}\text { Number of } \\
\text { stations }\end{array}$ & $\begin{array}{r}\text { Mean altitude } \\
(\mathrm{m})\end{array}$ & $\begin{array}{r}\text { Minimum } \\
(\mathrm{m})\end{array}$ & $\begin{array}{r}\text { Maximum } \\
(\mathrm{m})\end{array}$ \\
\hline Marine & 17 & 13.8 & 0 & 101 \\
Mountain & 16 & 430.2 & 303 & 1485 \\
Desert & 15 & 120.0 & 114 & 204 \\
\hline
\end{tabular}

\subsubsection{Verification and diagnostics}

All comparisons were made using NCAR's Model Evaluation Tools V9.0 (MET) package (Brown et al., 2020), utilizing a nearest-grid cell approach on an hourly temporal resolution.

To obtain a visual overview of model performance, in terms of closeness of fit, spread of forecast errors, and distribution of residuals, scatterplots divided by region and daynight period are shown in Fig. 5. Included are a line of best fit for the data, a 1:1 line of perfect fit, and a $95 \%$ confidence ellipse. Then, we plotted regional seasonal statistics of the mean observations $\left(T_{2 \mathrm{~m}}, \mathrm{TD}_{2 \mathrm{~m}}\right.$, and $\left.\mathrm{UV}_{10 \mathrm{~m}}\right)$ (Fig. 6).

To quantify the regional forecast-observation association, error magnitude, and sign during day and night, we show three standard statistical diagnostics:

- Pearson correlation coefficient

- root mean square error (RMSE)

- bias.

The Pearson correlation coefficient " $r$ " measures the strength of linear association between forecast $(f)$ and observation $(o)$, at all stations at each time step, given as follows:

$r=\frac{\sum_{i=1}^{\mathrm{ns}}\left(f_{i}-\bar{f}\right)\left(o_{i}-\bar{o}\right)}{\sqrt{\sum_{i=1}^{\mathrm{ns}}\left(f_{i}-\bar{f}\right)^{2}} \sqrt{\sum_{i=1}^{\mathrm{ns}}\left(o_{i}-\bar{o}\right)^{2}}}$,

where $f_{i}$ and $o_{i}$ are the forecast and observation at each observation point $i, \bar{f}$, and $\bar{o}$ are forecast and observation averages, ns indicates the total number of observations at each time step (i.e., number of stations), and overbars indicate the mean. Occasionally ns was reduced slightly whenever a missing value occurred.

The RMSE is a scale-dependent diagnostic defined simply as the square root of the mean square error (MSE) of the forecast:

$\operatorname{RMSE}=\sqrt{\mathrm{MSE}}=\sqrt{\frac{1}{\mathrm{~ns}} \sum_{i=1}^{\mathrm{ns}}\left(f_{i}-o_{i}\right)^{2}}$.
The bias is a measure of overall error, including sign, defined as follows:

bias $=\frac{1}{\mathrm{~ns}} \sum_{i=1}^{\mathrm{ns}}\left(f_{i}-o_{i}\right)=(\bar{f}-\bar{o})$.

These diagnostics were generated for 2015 for the region and time period and their temporal distribution expressed in boxplots (Sect. 3; Fig. 7) showing mean, median, $25 \%-$ $75 \%$ percentiles (box range), and $5 \%$ and $95 \%$ percentiles (whiskers).

Finally, a closer look at the diurnal evolution of the forecast is useful to investigate performance at specific times of day, such as local noon and at PBL transition periods, where models often have biases. Hence, we generated mean hourly cycles of the spatial mean and spatial standard deviations for both forecast and observations. The mean at each hour is calculated as follows:

$\operatorname{mean}(h)=\frac{1}{T} \sum_{t=1}^{T} \frac{1}{\mathrm{~ns}} \sum_{i=1}^{\mathrm{ns}} o_{i}$ or $f_{i}$.

The spatial standard deviation $(\sigma)$ at each hour is given as follows:

$\sigma(h)=\frac{1}{T} \sum_{t=1}^{T} \sqrt{\frac{1}{\mathrm{~ns}-1} \sum_{i=1}^{\mathrm{ns}}\left(o_{i}-\bar{o}\right)^{2}}$ or $f_{i}-\bar{f}$.

For the diurnal analysis, we selected the two most extreme seasons in terms of temperature - the (coolest) winter period of January-February (Fig. 8) and the (warmest) summer period of June-August (Fig. 9) 2015. Again, these figures are divided by region.

\section{Results and discussion}

In this section, we present a discussion of the results. Before examining the model performance however, we first discuss the study period of 2015 in the context of the long-term climate and El Niño (Sect. 3.1) to assess the representativeness of the 2015 study period. We then discuss differences in regional climate and their significance to our verification (Sect. 3.2). Finally, we evaluate the regional model output of $T_{2 \mathrm{~m}}, \mathrm{TD}_{2 \mathrm{~m}}$, and $\mathrm{UV}_{10 \mathrm{~m}}$ fields across the seasons and time of day (Sect. 3.3).

\subsection{5 in context}

Our study period is from 1 January to 30 November 2015 (during which time the full verification dataset was available). The year 2015 was considered one of the strongest $\mathrm{El}$ Niño periods since 1950 (L'Heureux et al., 2017) with an Oceanic Niño Index (ONI) index of up to 2.6 towards the end of the year (see Table 4). A high positive ONI indicates a stronger El Niño event (a negative ONI indicates La Niña 

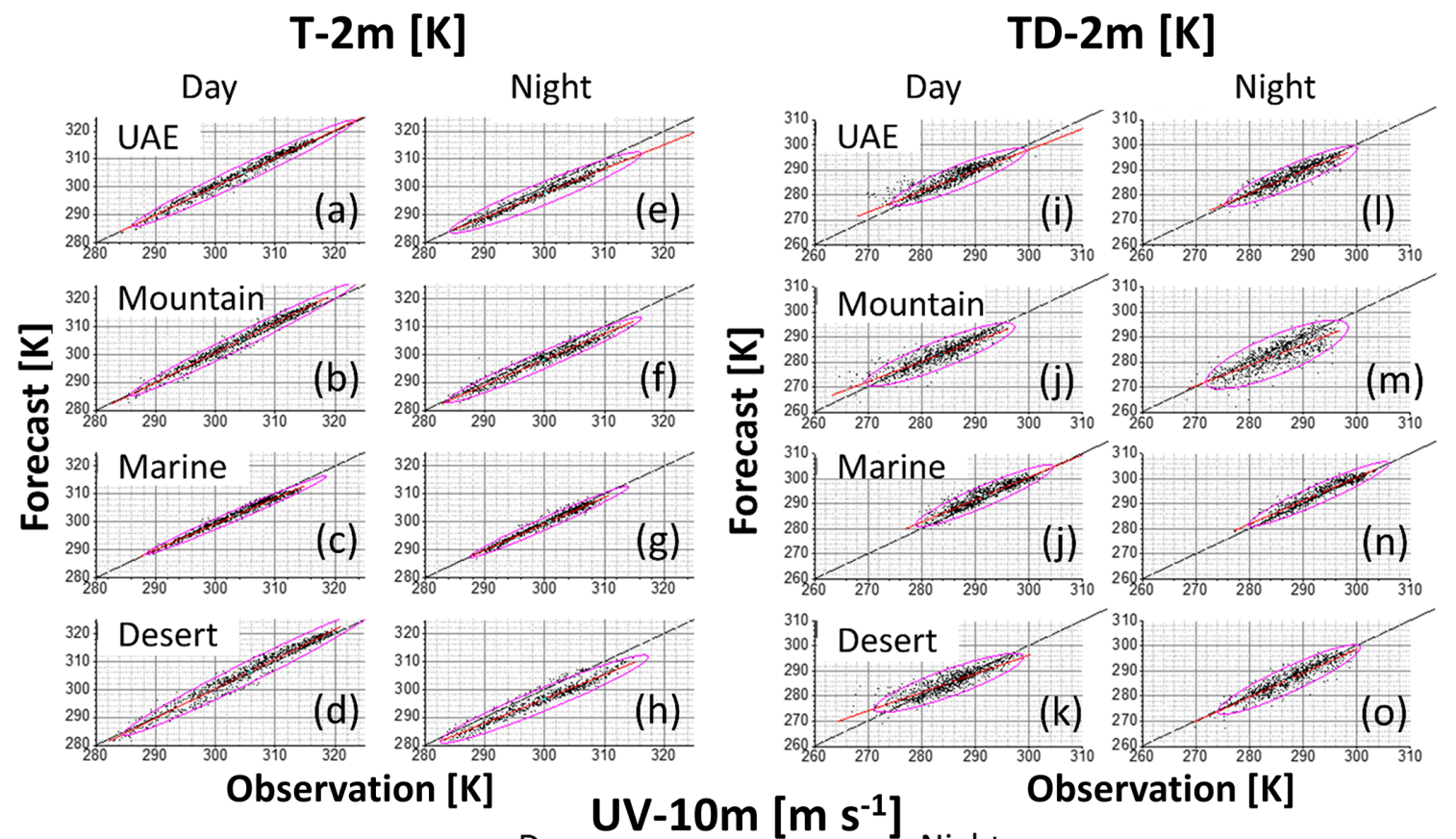

Day
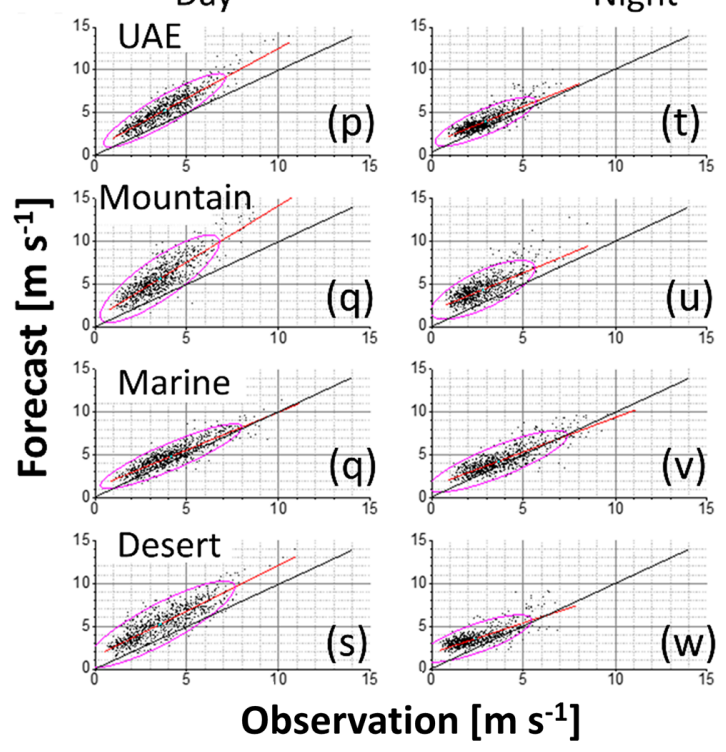

Figure 5. Scatter plots of forecast vs. observation for all time steps over the period of January-November 2015, comparing each weather station at the corresponding WRF grid point. The plots are split by daytime (06:00-17:00 LT, left panels) and nighttime periods (18:0005:00 LT, right panels), and by region (UAE, mountain, marine, desert). The variables compared are $2 \mathrm{~m}$ air temperature $\left(T_{2} \mathrm{~m}, \mathrm{~K}\right)$ in panels (a)-(h), $2 \mathrm{~m}$ dew point $\left(\mathrm{TD}_{2 \mathrm{~m}}, \mathrm{~K}\right)$ in panels (i)-(o), and $10 \mathrm{~m}$ wind speed $\left(\mathrm{UV}_{10 \mathrm{~m}}, \mathrm{~m} \mathrm{~s}^{-1}\right)$ in panels (p)-(w). Also shown is a line of best fit (red), a line of perfect fit (black), and $95 \%$ confidence ellipse (magenta).

events). El Niño-Southern Oscillation (ENSO) is known to impact upon the climate in this region, including temperatures and precipitation in the UAE (AlEbri et al., 2016; Almazroui, 2012; Chandran et al., 2016), so one might expect significant climate anomalies during 2015. Hence, a comparison was made between the long-term climatology and the year 2015, based on ECMWF ERA5 reanalysis data. In Figs. 2 and 3, from the geopotential height field, we can see that a positive 2015 winter temperature anomaly exists to the north of the UAE, extending from Turkey to the Caspian Sea (Fig. 2, top left). However, conditions over the UAE show less deviation in terms of the temperature, pressure, and wind fields. As the year progresses, and the ONI increases, the temperature anomaly becomes more pronounced further south, especially in JJA when higher 2015 temperatures extend further south toward Oman and Yemen than is apparent 

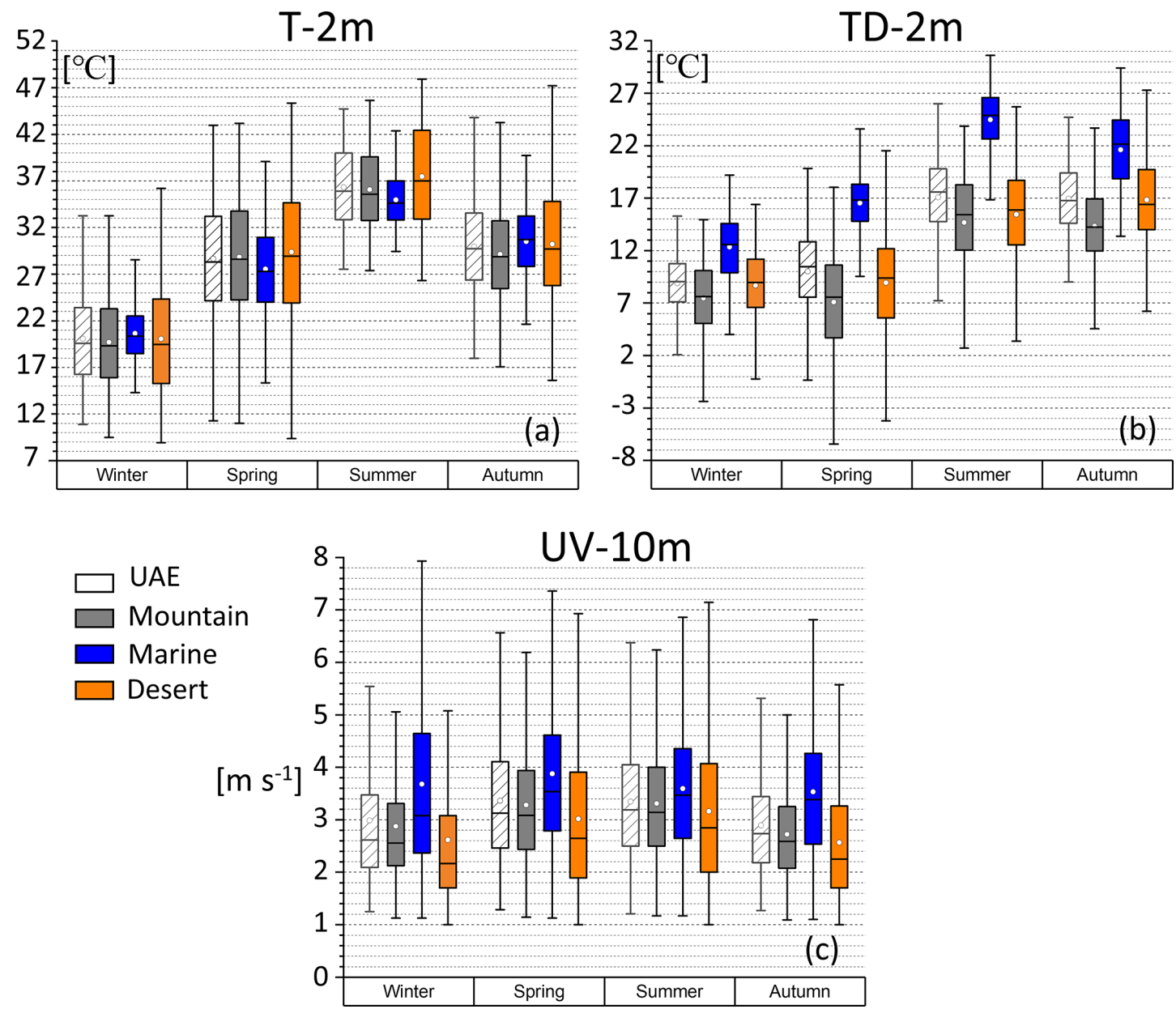

Figure 6. Regional seasonal statistics of mean observations: $T_{2} \mathrm{~m}(\mathbf{a}), \mathrm{TD}_{2 \mathrm{~m}}(\mathbf{b})$, and $\mathrm{UV}_{10 \mathrm{~m}}(\mathbf{c})$. Box plots show the mean as a center line and median as a dot; box ends are $25 \%$ and $75 \%$ percentiles, and whiskers are $5 \%$ and $95 \%$ percentiles.

in the climatology (Fig. 3a and b). Overall though, synoptic conditions over the Arabian Peninsula do not appear to be markedly different. They are similar enough, in fact, to consider the 2015 regional climate as representative of the climate in general.

\subsection{Regional and seasonal characteristics}

An assessment of regional distributions reveals that clear differences in means and variability do exist (Fig. 6). As expected, the marine region is dominated by the Arabian Gulf characteristics, with more moderate temperature maxima and minima (Fig. 6a), greater humidity (Fig. 6b), and higher wind speeds (Fig. 6c) than the inland desert (Fig. 6). Hence marine temperatures are lower than at the desert stations in the summer months but remain higher in winter and autumn. In fact, the desert stations have the most extreme $T_{2} \mathrm{~m}$ range in all seasons, reflecting the lower heat capacity surface, and consequent strong daytime surface heating. Rapid nocturnal cooling also occurs due to radiative losses in a much drier inland environment. The mountain region is only a little cooler than the desert $\left(\sim 1^{\circ} \mathrm{C}\right)$ in summer and autumn with the difference further reduced during spring and winter. The majority of mountain stations are located at fairly moderate altitudes (mean altitude $430 \mathrm{~m}$; Table 3 ) with only one station located over $1000 \mathrm{~m}$ high (station ID 41229 - $1485 \mathrm{~m}$ a.s.l.; see Table A1 in Appendix). Even so, one might have expected larger differences. However, there could be reasons other than the temperature lapse rate for this, such as differences in mountain and desert cloud cover (Branch et al., 2020a; Yousef et al., 2019) or in albedo (e.g., Nelli et al., 2020b).

$\mathrm{TD}_{2 \mathrm{~m}}$, or dew point temperature, is a standard measure of humidity and is in most cases relatively independent of the ambient temperature. It is also a reliable measure of how humid the air feels in terms of human comfort (Wood, 1970). In a hot (and warming) climate like the UAE, forecasting $\mathrm{TD}_{2 \mathrm{~m}}$ accurately is therefore important for society. Regionally, we observe considerable differences in $\mathrm{TD}_{2} \mathrm{~m}$ (Fig. 6b), which are more or less expected due to coastal-land gradients and variation in vertical transport and distribution of va- 


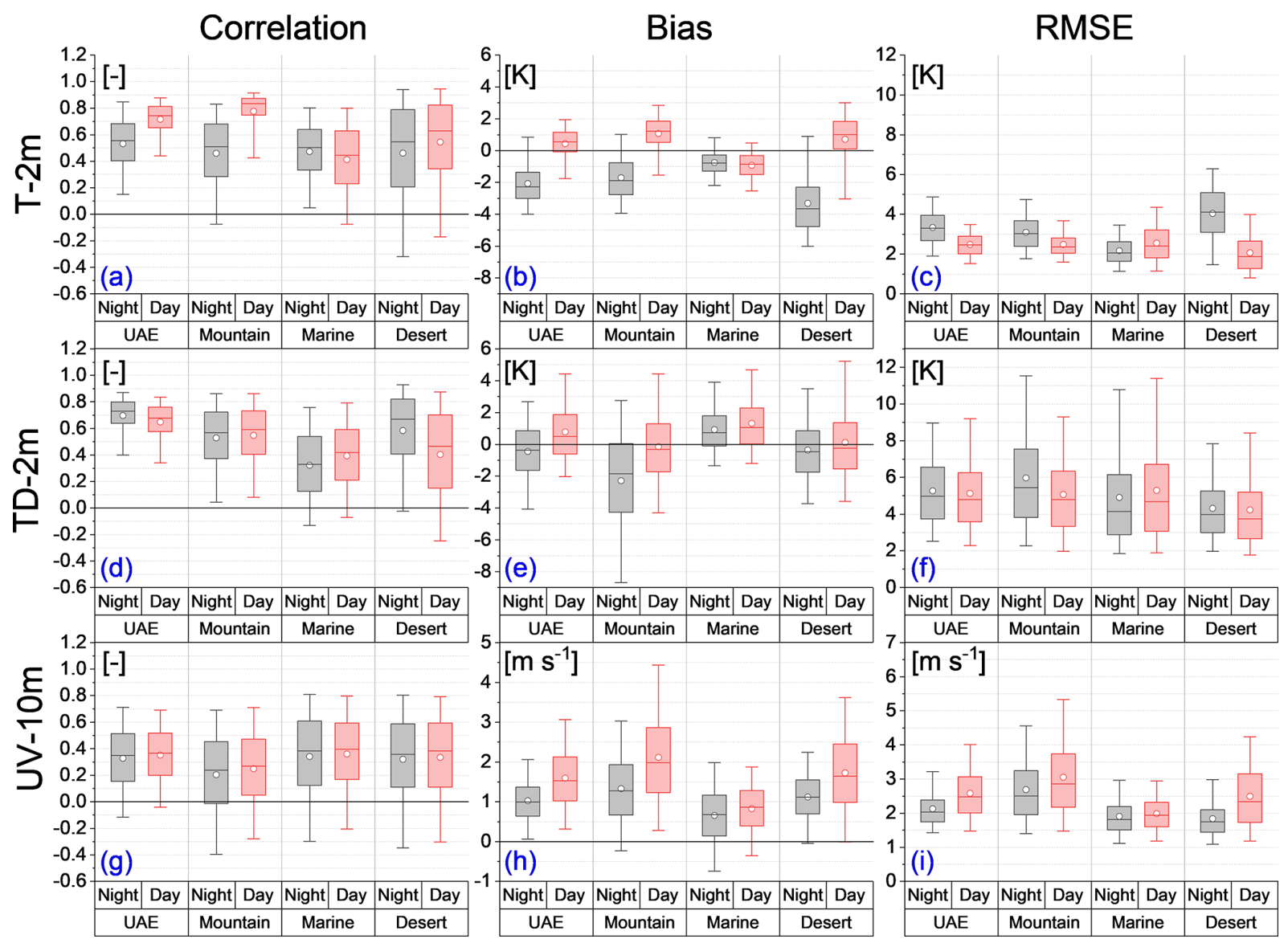

Figure 7. Box plots of $T_{2} \mathrm{~m}, \mathrm{TD}_{2 \mathrm{~m}}$, and $\mathrm{UV}_{10 \mathrm{~m}}$ (respectively, panels a-c, $\mathbf{d}-\mathbf{f}$, and $\mathbf{g}-\mathbf{i}$ ) for all time steps over the period of JanuaryNovember 2015. Statistics are divided by region (UAE, mountain, marine, desert) and then by nighttime and daytime hours (respectively, night 18:00-05:00 (grey boxes) and day 06:00-17:00 (red boxes) in local time). Statistics shown are Pearson correlation (a, d, g), bias (b, e, h), and RMSE (c, f, i). On the box plots the center line represents the mean, the white circle is the median, box ends represent $25 \%$ and $75 \%$ percentiles, and the whiskers are $5 \%$ and $95 \%$ percentiles. Also marked is a horizontal zero reference line for the Pearson and bias statistics.

Table 4. The 2015 Oceanic Niño Index (ONI) (3-month running mean of ERSST.v5 SST anomalies in the Niño 3.4 region at $50^{\circ} \mathrm{N}-50^{\circ} \mathrm{S}$, $\left.120-170^{\circ} \mathrm{W}\right)$, based on centered 30 -year base periods updated every 5 years - NOAA.

\begin{tabular}{rrrrrrrrrrrr}
\hline Jan & Feb & Mar & Apr & May & Jun & Jul & Aug & Sep & Oct & Nov & Dec \\
\hline 0.6 & 0.6 & 0.6 & 0.8 & 1 & 1.2 & 1.5 & 1.8 & 2.1 & 2.4 & 2.5 & 2.6 \\
\hline
\end{tabular}

por in different environments. Table 5 shows the difference in observed $T_{2 \mathrm{~m}}$ and $\mathrm{TD}_{2 \mathrm{~m}}$ means. The inland atmosphere tends to be humid in summer when temperatures are high but even closer to saturation in autumn and winter as temperatures fall, but humidity remains high. This seasonal range is particularly pronounced in the mountain regions, reflecting the predominance of annual rainfall occurring during winter in the mountains and gravel plains of the northeastern part of the UAE (Sherif et al., 2014; Wehbe et al., 2019). In all seasons, the marine region is closer to saturation than in the other regions $\left(T_{2 \mathrm{~m}}\right.$ minus $\mathrm{TD}_{2 \mathrm{~m}}$ range is 8.3 to $\left.11^{\circ} \mathrm{C}\right)$; however, this contrast is reduced in the cooler seasons as the mountain and desert regions become more humid.

There are significant regional differences in $\mathrm{UV}_{10 \mathrm{~m}}$, with marine $\mathrm{UV}_{10 \mathrm{~m}}$ being $0.5-1 \mathrm{~m} \mathrm{~s}^{-1}$ higher than in other regions (Fig. 6c) and also more variable. This is not unexpected, due to low surface roughness, strong land-sea temperature gradients, and associated land-sea breezes. Desert $\mathrm{UV}_{10 \mathrm{~m}}$ is the lowest all year round, and mountain $\mathrm{UV}_{10 \mathrm{~m}}$ falls in between those of the desert and marine regions. In general, $\mathrm{UV}_{10 \mathrm{~m}}$ is highest in spring and autumn. 

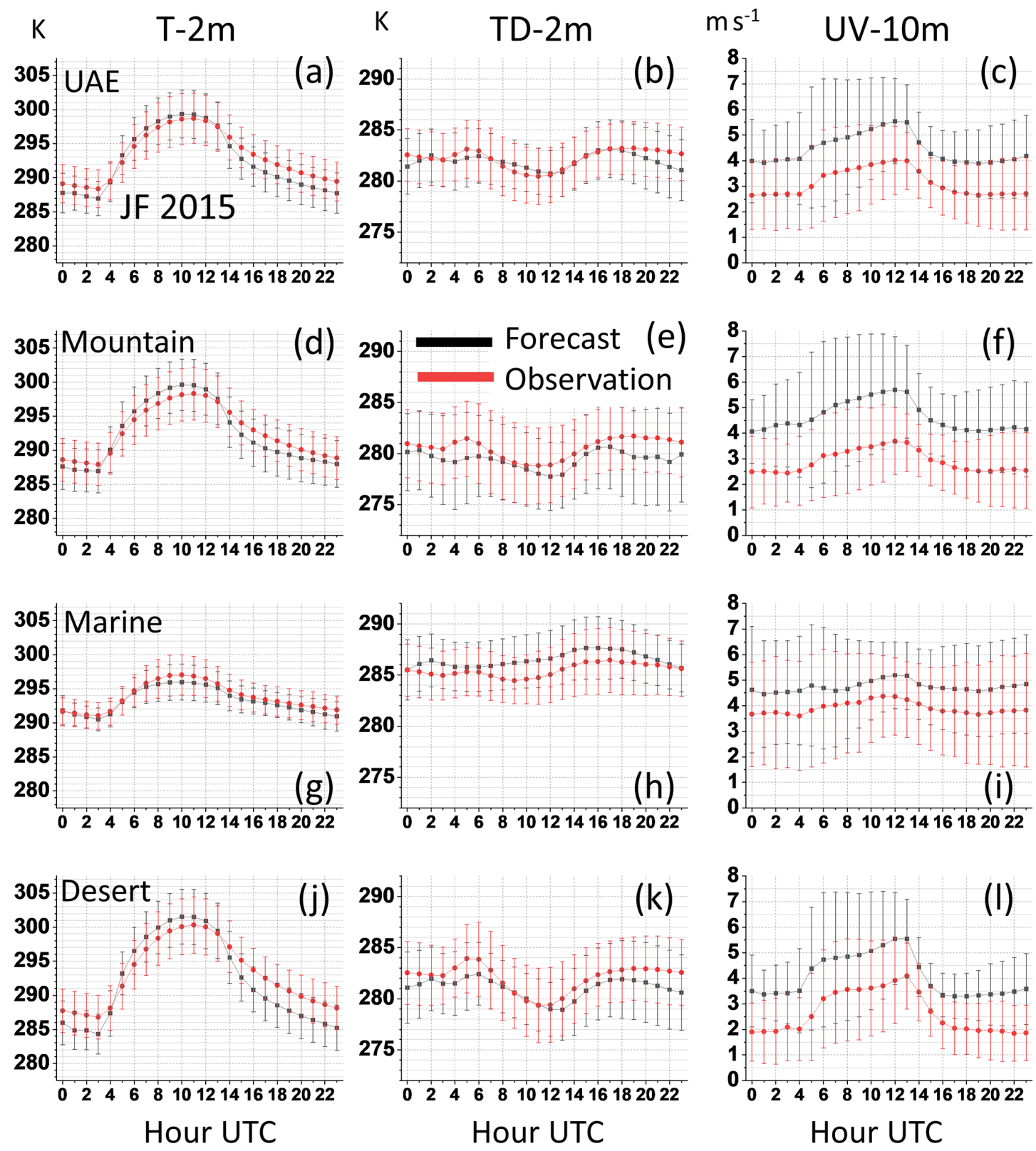

Figure 8. Winter diurnal cycles of spatial mean values of forecast (black lines) vs. observations (red) - January-February 2015. The error bars represent the mean spatial standard deviation for each hour. Variables shown are $T_{2 \mathrm{~m}}$ (K, left panels), TD $2 \mathrm{~m}(\mathrm{~K}$, center), and UV-10 $\left(\mathrm{m} \mathrm{s}^{-1}\right.$, right). Again the statistics are divided by region: UAE (top row), mountain (second row), marine (third row), desert (fourth row).

These regional differences justify the need for regional splitting of the dataset and are further addressed below, in conjunction with model performance.

\subsection{Model evaluation}

Although the simulation of $T_{2 \mathrm{~m}}, \mathrm{TD}_{2 \mathrm{~m}}$, and $\mathrm{UV}_{10 \mathrm{~m}}$ and causes for any biases may be physically linked, we nevertheless first examine each field individually for clarity.

\subsection{1 $\quad T_{2 m}$}

In the scatter plots (Fig. 5a-h) we observe that in the daytime, $T_{2} \mathrm{~m}$ appears to be well estimated for the UAE on the whole (Fig. 5a) $\left(+0.44{ }^{\circ} \mathrm{C}\right)$, and errors are well distributed over the $T_{2 \mathrm{~m}}$ range. However, this agreement obscures some compensating regional biases; namely overestimation in the desert $\left(+0.71^{\circ} \mathrm{C}\right)$ and mountains $\left(+1.06^{\circ} \mathrm{C}\right)$, and underestimation in the marine region $\left(-0.93{ }^{\circ} \mathrm{C}\right)$.

Reasons for the warm bias may be attributable to a combination of reasons. Firstly, a WRF overestimation of down- 
Table 5. Seasonal and regional differences in observed $T_{2} \mathrm{~m}$ and $\mathrm{TD}_{2 \mathrm{~m}}$ means to show the closeness to saturation. Included are the number of time steps for each season $\left(N_{\mathrm{T}}\right)$. Note that this is not a mean of the differences between $T_{2 \mathrm{~m}}$ and $\mathrm{TD}_{2 \mathrm{~m}}$ calculated at each time step, but an overall difference in means.

\begin{tabular}{llrr}
\hline Season & Region & $\begin{array}{r}N_{\mathrm{T}} \\
\text { total }\end{array}$ & $\begin{array}{r}\text { Mean }\left(T_{2 \mathrm{~m}}-\mathrm{TD}_{2 \mathrm{~m}}\right) \\
{\left[{ }^{\circ} \mathrm{C}\right]}\end{array}$ \\
\hline Winter & UAE & 1416 & 11.2 \\
Winter & Mountain & 1416 & 12.2 \\
Winter & Marine & 1416 & 8.3 \\
Winter & Desert & 1416 & 11.4 \\
Spring & UAE & 2207 & 18.6 \\
Spring & Mountain & 2207 & 21.7 \\
Spring & Marine & 2207 & 11.0 \\
Spring & Desert & 2207 & 20.4 \\
Summer & UAE & 2207 & 19.2 \\
Summer & Mountain & 2208 & 21.4 \\
Summer & Marine & 2208 & 10.5 \\
Summer & Desert & 2207 & 22.0 \\
Autumn & UAE & 2042 & 13.0 \\
Autumn & Mountain & 2182 & 14.8 \\
Autumn & Marine & 2176 & 8.9 \\
Autumn & Desert & 2051 & 13.4 \\
\hline
\end{tabular}

welling surface shortwave radiation has been observed before (Fonseca et al., 2020; Nelli et al., 2020b). This has been attributed to a lack of cloud cover but may also relate to the performance of the radiative transfer scheme and interaction with aerosols. Secondly, the soil representation, such as soil texture classification - and associated parameters like heat capacity, thermal diffusivity, and albedo - may require adjustment. Underestimations of albedo in WRF have recently been observed, particularly for bright desert soils where measurements show typical albedo values of 0.3 to 0.34 (Nelli et al., 2020b). The WRF albedo value in this study is around 0.23 for much of the UAE lowlands, which would likely result in an overly high net radiation and sensible heating, especially on dry soils. This is consistent with the reported positive daytime temperature biases in the inland desert. A third factor may be the prescribed aerodynamic roughness length parameters used by WRF. Nelli et al. (2020a) found that a new value for the parameter, derived from eddy covariance measurements, reduced the warm daytime bias in WRF simulations (Nelli et al., 2020b). These causes may account for some or all of the daytime temperature biases and therefore need to be considered for future simulations in this region.

Nocturnally, we observe a cold bias over the UAE (Fig. 5e). This is quantified in Fig. $7 \mathrm{~b}$ as a mean negative bias of just over $-2{ }^{\circ} \mathrm{C}$. One can also see that this nocturnal bias tends to worsen with an increase in daily $T_{2 \mathrm{~m}}$, which implies that the cold bias gets worse in the hotter months. This is confirmed in the seasonal diurnal cycles (Figs. 8a and 9a), where the mean nocturnal bias in winter is $\sim-2^{\circ} \mathrm{C}$ but increases to greater than $-4^{\circ} \mathrm{C}$ in summer. This nocturnal cold bias is re- flected in all sub-regions, but not to the same degree. The best nocturnal performance is in the marine region (Fig. $5 \mathrm{~g}$ ) (bias of $-0.75^{\circ} \mathrm{C}$ ), with an even error distribution across the temperature range. The largest nocturnal cold bias is in the desert region $\left(-3.1^{\circ} \mathrm{C}\right)(\mathrm{Fig} .5 \mathrm{~h})$, with a steady increase in bias with temperature. The switch from positive to cold biases usually occurs more or less around the twice-daily transition times of the boundary layer between stable and convective states. Such arid nocturnal biases have been noted before (Branch et al., 2014; Fekih and Mohamed, 2017; Weston et al., 2019). It may be that an overly dry lower atmosphere results in a lower downward flux of longwave radiation, as found by Fonseca et al. (2020) in a comparison of WRF with radiation measurements. All else being equal this dryness would lead to a reduction of "buffering" at nighttime. They also found an overly high upward ground heat flux during the night, which could be associated with sub-optimal soil parameters or an overly strong soil-air temperature gradient. Overall, their net radiation losses at night were higher in WRF than from the radiation measurements.

\subsection{2 $\quad \mathrm{TD}_{2 \mathrm{~m}}$}

$\mathrm{TD}_{2 \mathrm{~m}}$ is relatively well estimated in 2015 over the UAE as a whole, with correlations around 0.7 and biases of less than $1{ }^{\circ} \mathrm{C}$ (Fig. 7d and e, UAE sections). However, we can look at regional and seasonal differences for more detail. In the desert and marine regions, the biases are $\leq 1{ }^{\circ} \mathrm{C}$ during both day and night. Marine $\mathrm{TD}_{2 \mathrm{~m}}$ is slightly overestimated in general, indicating the model to be more humid over the gulf and coast than observed. Mountain nocturnal dew points are more of a problem with a negative bias of $\sim-2{ }^{\circ} \mathrm{C}$, and a larger error spread than the other regions (Fig. 7e). There is also a corresponding $T_{2 \mathrm{~m}}$ nocturnal bias of $\sim-2{ }^{\circ} \mathrm{C}$ which could indicate a deficiency in the longwave surface budget as just mentioned, but also a model deficiency in representing the intermittent shear-driven turbulence that appears in nighttime stable boundary layers. However, such biases in complex terrain have been already well documented (e.g., Warrach-Sagi et al., 2013; Zhang et al., 2013). One of the reasons cited is that the $\mathrm{CP}$ scale is not fine enough to resolve mountain slopes and therefore cannot capture certain processes in the same way that large-eddy scale models can, with grid spacings on the order of $\Delta x=100 \mathrm{~m}$. However, while such fine resolutions may be appropriate in a research context, they may remain prohibitively expensive and inappropriate in the context of operational forecasting.

An additional problem in complex terrain is the validity of the traditional Monin-Obukhov similarity theory (MOST) (e.g., see Foken, 2006) that is typically used in atmospheric models, including WRF, for calculation of model diagnostics like $T_{2 \mathrm{~m}}$ or $\mathrm{TD}_{2 \mathrm{~m}}$. MOST assumes homogeneous underlying land surface and stationary fluxes, and there is plenty of evidence that in complex and heterogeneous landscapes MOST needs significant improvements in scaling of turbu- 
lent kinetic energy profiles in the lowest part of the boundary layer (e.g., Figueroa-Espinoza et al., 2014; Wulfmeyer et al., 2018). The latter may affect representation of the heat, moisture, and momentum transport from the land surface to the atmosphere, and if misrepresented may lead to such high biases in the surface layer model diagnostics.

Seasonally, diurnal $\mathrm{TD}_{2 \mathrm{~m}}$ is quite well reproduced in both winter and summer (Figs. 8 and 9). The mountain nocturnal negative bias becomes more significant in summer (Fig. 9e). In the desert, a positive bias occurs over midday starting around 10:00 LT (Fig. 9k) showing an overestimation of water vapor in summer. This is likely to be too early in the day for a sea-breeze-driven anomaly but may relate to simulated soil moisture being higher than reality. This was observed in a study by Wehbe et al. (2019) that found a wet bias in dry soils and a dry bias in wetter soils in WRF over the UAE when not coupled with a more advanced hydrological model.

\subsection{3 $\mathrm{UV}_{10 \mathrm{~m}}$}

WRF overestimates $\mathrm{UV}_{10 \mathrm{~m}}$ during the day and night, in all regions and seasons. Positive biases of $1-2 \mathrm{~m} \mathrm{~s}^{-1}$ are typical over the whole year (seen in Fig. 7h). Mountain daytime biases are strongest at $2 \mathrm{~m} \mathrm{~s}^{-1}$, followed by daytime desert biases at $1.5 \mathrm{~m} \mathrm{~s}^{-1}$. Marine biases are lowest with mean biases of $<1 \mathrm{~m} \mathrm{~s}^{-1}$. Notably, there is a trend where positive biases increase with wind speed (Fig. 5p, q, s). There is a significant increase in bias during the daytime, and also in the summer, particularly in the mountain and desert regions (Fig. 9f and i). In fact, the strongest wind biases occur in the same situations when daytime $T_{2} \mathrm{~m}$ is overestimated, particularly in the mountain and desert regions (Figs. 7, 8, 9), hinting at a relationship between the two. Indeed, it is likely that an overly strong sea breeze may account for this. During summer, the desert-marine $T_{2 \mathrm{~m}}$ daytime gradient is highest $\left(\sim 5^{\circ} \mathrm{C}\right.$; see Fig. $9 \mathrm{~g}$ and $\mathrm{j}$, red curves) than in winter $\left(\sim 3^{\circ} \mathrm{C}\right.$; see Fig. $8 \mathrm{~g}$ and j), although the seasonal warmth biases are similar $\left(\sim 1.5-2^{\circ} \mathrm{C}\right)$. The higher gradient coincides with a greater $\mathrm{UV}_{10 \mathrm{~m}}$ bias in summer. Weston et al. (2019) improved the duration and direction of UAE sea breezes by tuning a thermal roughness length parameter in WRF. The PBL and surface layer parameterization schemes could also be a cause of the bias. Schwitalla et al. (2020) found an overestimation of $\mathrm{UV}_{10 \mathrm{~m}}$ in all members of a UAE physics ensemble, with magnitudes of around $1.5 \mathrm{~m} \mathrm{~s}^{-1}$. The bias was worse when using the MYNN 2.5 TKE PBL and MYNN surface layer schemes, when compared with the Yonsei University (YSU) scheme (Hong et al., 2006) paired with the MM5 Jiménez surface layer scheme (Jiménez et al., 2012).

Using a non-local PBL scheme like YSU tends to produce a deeper and drier PBL with a stronger vertical mixing, in comparison to local schemes like MYNN (see Milovac et al., 2016; Yang et al., 2017). This may lead to a reduction in wind speeds, heat, and moisture close to the surface. However, another study found that switching between seven different PBL schemes had little effect on positive UV bias (Shimada et al., 2011). One additional factor is that there are several parameters within the MYNN scheme itself, which may benefit from retuning for arid regions like the UAE (e.g., Yang et al., 2017). However, the total impact of the PBL scheme selection on reproduction of the $T_{2} \mathrm{~m}, \mathrm{TD}_{2 \mathrm{~m}}$, and $\mathrm{UV}_{10 \mathrm{~m}}$ diagnostics is not completely clear. This is because, depending on the land surface type, the calculations of transfer coefficients/fluxes are made in Noah-MP, the PBL scheme, or the surface layer scheme (SLS). In WRF, PBL schemes are generally coupled to the SLS, and typically all variables between the land surface and lowest model layer are diagnosed (e.g. $T_{2 \mathrm{~m}}, U-10 \mathrm{~m}, V-10 \mathrm{~m}$ ). These calculations in the SLS are based on Monin-Obukhov similarity theory and are represented in the model as hard-coded parameters and/or formulations of similarity functions. The latter are used to obtain dimensionless bulk transfer coefficients which are used for calculating momentum, heat, and moisture fluxes, and for diagnosing near-surface quantities like $T_{2 \mathrm{~m}}$. These coefficients re-enter the LSM and are to calculate the surface fluxes which then enter the PBL scheme, as the lower boundary condition. Therefore, bias in near-surface variables is strongly related to the choice of LSM and SLS. In this WRF configuration, the communication link between the SLS and NOAH-MP is broken, as NOAH-MP itself calculates transfer coefficients and diagnostics over land surfaces, effectively bypassing the SLS (Nielson et al., 2013). The SLS only becomes active over water surfaces. This means that when NOAH-MP is used, the LSM probably has a stronger impact on the bias of near surface variables than the PBL and SLS (e.g., Milovac et al., 2016).

Incorrect aerodynamic roughness length parameters, as mentioned previously, may also play a large role in determining $\mathrm{UV}_{10 \mathrm{~m}}$ - this parameter is used within the surface layer scheme. Nelli et al. (2020a) found positive wind speed biases over the same region when wind speeds were $<4 \mathrm{~m} \mathrm{~s}^{-1}$ and negative biases for wind speeds which were $>6 \mathrm{~m} \mathrm{~s}^{-1}$ within a WRF V3.8 simulation. We have a similar behavior at night in the marine and desert regions, as exhibited by the positive-to-negative distribution of errors increasing with wind speed. Nelli et al. (2020a) reduced these biases by retuning the roughness length parameter based on eddy covariance measurements (Nelli et al., 2020b).

Another possibility is the length of the forecast spin-up, the required length of which may still be uncertain. We have already mentioned that Chaouch et al. (2017) cited a $5 \mathrm{~h}$ spinup as being sufficient, but Hahmann et al. (2015) posit that the necessary spin-up over land could be $12 \mathrm{~h}$ or even more (primarily for effective use of the PBL scheme). However, such long spin-ups are likely to be (i) prohibitively expensive and (ii) too time consuming for forecasting purposes. 

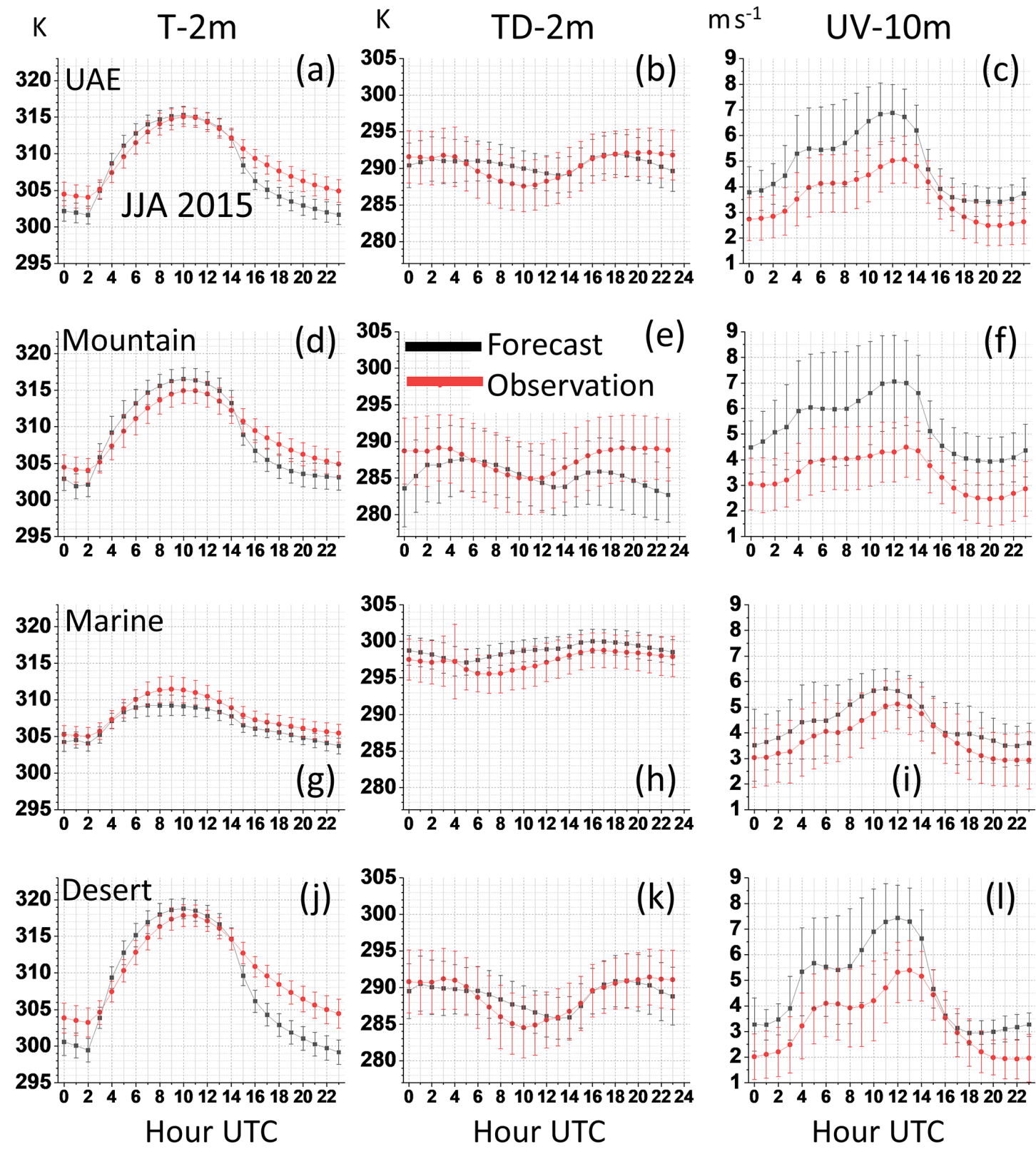

Figure 9. Summer diurnal cycles. As for Fig. 8 except for the period June-August 2015.

\section{Summary and outlook}

The aim of this study was to (i) assess the skill of WRF with Noah-MP in reproducing surface quantities over the UAE; (ii) identify regional, seasonal, and diurnal differences in performance; and (iii) estimate potential sources of model deficiencies. We have demonstrated the value of splitting the model evaluation temporally and spatially. While assessment of diagnostics for the whole UAE region remains useful, it can obscure regional, diurnal, and seasonal differences, as well as compensating biases. These are all scientifically interesting factors. Importantly, they might reveal information on model performance with respect to specific processes and land surface types, and how they are simulated.

An analysis of model predictions has revealed that WRF with Noah-MP represents the mean $T_{2} \mathrm{~m}$ field reasonably well during the daytime, although with a tendency for slight overestimation $\left(\leq 1{ }^{\circ} \mathrm{C}\right)$. The nocturnal $T_{2} \mathrm{~m}$ is underestimated more strongly though $\left(1-4{ }^{\circ} \mathrm{C}\right)$, and with larger biases during the hotter months, particularly in the desert and mountains, likely due to a combination of deficiencies. The marine region has the lowest $T_{2} \mathrm{~m}$ biases, which is encouraging, and highlights the value of ingesting quality SST data, especially in coastal regions. WRF shows a good performance 
regarding $\mathrm{TD}_{2 \mathrm{~m}}$ in general, with mean biases being $\leq 1{ }^{\circ} \mathrm{C}$. Humidity over the marine region tends to be slightly overestimated though, whilst nocturnal mountain $\mathrm{TD}_{2 \mathrm{~m}}$ is underestimated (bias $\sim-2{ }^{\circ} \mathrm{C}$ ). $\mathrm{UV}_{10 \mathrm{~m}}$ performance on land still needs be improved, with biases of $1-2 \mathrm{~m} \mathrm{~s}^{-1}$. Furthermore, performance for $\mathrm{UV}_{10 \mathrm{~m}}$ tends to worsen during the hot months, particularly inland. $\mathrm{UV}_{10 \mathrm{~m}}$ in the marine region is generally much better simulated than in the other regions (bias $\leq 1 \mathrm{~m} \mathrm{~s}^{-1}$ ). There is an apparent relationship between $T_{2 \mathrm{~m}}$ bias and $\mathrm{UV}_{10 \mathrm{~m}}$ bias, and this could be due to deficiencies in sea-land breeze simulation. $\mathrm{TD}_{2 \mathrm{~m}}$ biases appear to be more independent. The only exception to this is during the night, when $T_{2} \mathrm{~m}$ and $\mathrm{TD}_{2 \mathrm{~m}}$ biases do appear linked.

Ultimately, no model downscaling forecast (at scales economically viable for forecasting) can be expected to exhibit exceptional skill in all conditions. A general caveat when evaluating models is that one must factor in a certain level of error in station or gridded observational datasets themselves (e.g., as discussed by Prein and Gobiet, 2017). Nevertheless, assuming a high level of observational accuracy, we have discussed several avenues for improvement in this application of WRF. For instance, we should continue to devise and ingest new and improved datasets for land cover, terrain and soil texture, and albedo. In particular, within a vegetationsparse region like the UAE, soil texture, moisture, and other parameters are likely to be of prime importance. Certainly, ingesting SST data appears to have been valuable, given the lower coastal biases in all variables.

We have mentioned several very useful experiments carried out on parameters like aerodynamic and thermal roughness lengths (Nelli et al., 2020a; Weston et al., 2019), as well as process-based observational studies related to the surface energy balance and verification studies (Fonseca et al., 2020; Nelli et al., 2020b). Further experiments should now be coordinated in order to improve model predictions further. In terms of parameterization schemes, ensemble experiments (in the manner of Chaouch et al., 2017; Milovac et al., 2016; and Schwitalla et al., 2020) are still required to identify optimal land surface-surface-layer-PBL-microphysics combinations for arid regions. Such studies can also address the tuneable parameters defined inside parameterization schemes similarly to those conducted by Quan et al. (2016) and Yang et al. (2017). The most relevant ones can then be measured during dedicated field campaigns and subsequently ingested in the model.

Seasonal-scale studies such as these are vital for accurate assessment of WRF nowcasting performance and to identify model deficiencies and areas for improvement. By combining seasonal verification with sensitivity tests, and process and observational studies, we will move towards improved forecasting systems for the UAE and other arid regions. 


\section{Appendix A: Observation stations}

See Table A1 for details on individual weather stations.

Table A1. List of weather stations used for verification of WRF, including ID, coordinates, altitude, and assigned region.

\begin{tabular}{|c|c|c|c|c|c|c|}
\hline Number & Name & Station ID & Longitude $\left({ }^{\circ} \mathrm{E}\right)$ & Latitude $\left({ }^{\circ} \mathrm{N}\right)$ & Altitude (m a.s.1.) & Region \\
\hline 1 & Al Aryam & 41202 & 54.1719 & 24.3083 & 11 & Marine \\
\hline 2 & Al Dhaid & 41203 & 55.8169 & 25.2369 & 104 & Desert \\
\hline 3 & Al Faqa & 41204 & 55.6214 & 24.7189 & 215 & Mountain \\
\hline 4 & Al Malaiha & 41209 & 55.8881 & 25.1306 & 152 & Desert \\
\hline 5 & $\mathrm{Al}$ Qor & 41212 & 56.1519 & 24.9064 & 228 & Mountain \\
\hline 6 & Al Ruwais & 41214 & 52.8497 & 24.0833 & 13 & Marine \\
\hline 7 & Al Shiweb & 41215 & 55.7981 & 24.7761 & 292 & Mountain \\
\hline 8 & Abu Dhabi & 41217 & 54.3278 & 24.4772 & 8 & Marine \\
\hline 9 & Al Ain & 41218 & 55.7933 & 24.2156 & 302 & Mountain \\
\hline 10 & Dalma & 41220 & 52.2914 & 24.4908 & 10 & Marine \\
\hline 11 & Damsa & 41221 & 55.4133 & 24.18 & 169 & Desert \\
\hline 12 & Dhudna & 41223 & 56.325 & 25.511 & 51 & Marine \\
\hline 13 & Falaj Al Moalla & 41224 & 55.8661 & 25.3378 & 96 & Desert \\
\hline 14 & Hamim & 41225 & 54.3028 & 22.9736 & 115 & Desert \\
\hline 15 & Hatta & 41226 & 56.138 & 24.811 & 304 & Mountain \\
\hline 16 & Jabal Hafeet & 41227 & 55.7753 & 24.0567 & 910 & Mountain \\
\hline 17 & Jabal Mebreh & 41229 & 56.1294 & 25.6469 & 1485 & Mountain \\
\hline 18 & Khatam Al Shaklah & 41230 & 55.9519 & 24.2111 & 406 & Mountain \\
\hline 19 & Madinat Zayed & 41231 & 53.6986 & 23.6817 & 113 & Desert \\
\hline 20 & Makassib & 41232 & 51.824 & 24.666 & 0 & Marine \\
\hline 21 & Manama & 41233 & 56.0081 & 25.3853 & 204 & Mountain \\
\hline 22 & Masafi & 41234 & 56.1172 & 25.4475 & 453 & Mountain \\
\hline 23 & Mezaira & 41235 & 53.7786 & 23.145 & 204 & Desert \\
\hline 24 & Mezyed & 41236 & 55.8478 & 24.0286 & 316 & Mountain \\
\hline 25 & Mukhariz & 41237 & 52.8778 & 22.9347 & 142 & Desert \\
\hline 26 & Owtaid & 41238 & 53.1028 & 23.3956 & 145 & Desert \\
\hline 27 & Qasyoura & 41240 & 54.8194 & 22.8286 & 95 & Desert \\
\hline 28 & Raknah & 41242 & 55.7081 & 24.3456 & 282 & Mountain \\
\hline 29 & Ras Musherib & 41243 & 51.65 & 24.33 & 0 & Marine \\
\hline 30 & Saih Al Salem & 41246 & 55.3119 & 24.8275 & 78 & Desert \\
\hline 31 & Sir Bani Yas & 41248 & 52.5978 & 24.3169 & 101 & Marine \\
\hline 32 & Sir Bu Nair & 41249 & 54.2339 & 25.22 & 4 & Marine \\
\hline 33 & Tawiyen & 41251 & 56.0703 & 25.56 & 164 & Desert \\
\hline 34 & Um Azimul & 41252 & 55.1386 & 22.7142 & 114 & Desert \\
\hline 35 & Um Ghafa & 41253 & 55.9333 & 24.0667 & 361 & Mountain \\
\hline 36 & Umm Al Quwain & 41254 & 55.6583 & 25.5333 & 12 & Marine \\
\hline 37 & Yasat & 41255 & 51.9883 & 24.1722 & 15 & Marine \\
\hline 38 & ALEjeili & 41256 & 54.1 & 25.02 & 0 & Marine \\
\hline 39 & Ajman & 41258 & 55.4 & 25.42 & 0 & Marine \\
\hline 40 & Al Rass & 41259 & 54.3 & 24.45 & 3 & Marine \\
\hline 41 & Al Ajban & 41260 & 54.9 & 24.6 & 51 & Desert \\
\hline 42 & Al Shuaibah & 41261 & 55.6 & 24.11 & 209 & Mountain \\
\hline 43 & Arylah & 41262 & 54.2 & 24.99 & 0 & Marine \\
\hline 44 & Ashaab & 41264 & 54.8 & 24.39 & 58 & Desert \\
\hline 45 & Jabal Yanas & 41266 & 56.1 & 25.73 & 684 & Mountain \\
\hline 46 & Ras Al Khaimah & 41267 & 55.94 & 25.77 & 7 & Marine \\
\hline 47 & Shoukah & 41269 & 56 & 25.11 & 232 & Mountain \\
\hline 48 & Abu Al Bukhoosh & 41274 & 53.146 & 25.495 & 0 & Marine \\
\hline
\end{tabular}


Code availability. To download the WRF source code, users need to register on the following website: http://www2.mmm.ucar.edu/ wrf/users/download/wrf-regist.php (last access: 1 March 2021). The namelist.input file, which is used for the WRF configuration, and scripts for running WRF in NWP mode are uploaded with open access to Zenodo: https://doi.org/10.5281/zenodo.3894491 (Branch et al., 2020b) Model Evaluation Tools V9.0 (MET) from the NCAR Research Applications Laboratory (generation of verification statistics) are open source and available from https://ral.ucar. edu/solutions/products/model-evaluation-tools-met (Brown et al., 2020). The NCAR Command Language (NCL) V6.2 (2019) consists of open-source graphics and is used for overwriting soil moisture data when running NWP mode. It is available from https: //www.ncl.ucar.edu/. Information on the ArcGIS V10.5 proprietary graphics and mapping can be found at https://www.esri.com/en-us/ arcgis/products/arcgis-desktop/overview (Esri, 2021). The Originlab 2020 V9.7.0.185 (Academic) proprietary statistical analysis and graphics are available from https://www.originlab.com/index.aspx? go=Products/Origin (OriginLab Corporation, 2021).

Data availability. WRF output data are available on reasonable request as they are extremely large in size (many TB). They are archived on the German Climate Computing Center (Deutsches Klimarechenzentrum, DKRZ) and will be there for a minimum of 10 years. Verification data were uploaded to Zenodo in the form of open-access Excel files. Data are courtesy of NCM and UAE. Observation data can be found at https://zenodo.org/deposit/3894544 (Branch et al., 2020c). The verification statistics dataset can be found at https://doi.org/10.5281/zenodo.4004195 (Branch et al., 2020d).

Author contributions. OB is the first author who conceived the experiment, carried out the simulations and analysis, and wrote the publication. TS contributed greatly to scientific support and cowriting of the paper, provided much technical assistance, and formatted the observation data for use in the MET software. MT, RF, $\mathrm{NN}, \mathrm{MW}$, and VW provided specialist scientific support and assisted with the drafting and improvement of key aspects of the paper.

Competing interests. The authors declare that they have no conflict of interest.

Acknowledgements. This material is based on work supported by the UAE Research Program for Rain Enhancement Science, under the National Center of Meteorology, Abu Dhabi, UAE. Furthermore, we are grateful to the High Performance Computing Center Stuttgart (HLRS) for providing support and computing time on the XC40 system. We are also grateful to ECMWF for providing operational analysis data.

Review statement. This paper was edited by Volker Grewe and reviewed by two anonymous referees.

\section{References}

Al Azhar, M., Temimi, M., Zhao, J., and Ghedira, H.: Modeling of circulation in the Arabian Gulf and the Sea of Oman: Skill assessment and seasonal thermohaline structure, J. Geophys. Res.-Oceans, 121, 1700-1720, https://doi.org/10.1002/2015JC011038, 2016.

Albergel, C., de Rosnay, P., Balsamo, G., Isaksen, L., and MuñozSabater, J.: Soil Moisture Analyses at ECMWF: Evaluation Using Global Ground-Based In Situ Observations, J. Hydrometeorol., 13, 1442-1460, https://doi.org/10.1175/JHM-D-11-0107.1, 2012.

Aldababseh, A. and Temimi, M.: Analysis of the Long-Term Variability of Poor Visibility Events in the UAE and the Link with Climate Dynamics, Atmosphere (Basel), 8, 242, https://doi.org/10.3390/atmos8120242, 2017.

AlEbri, M., Arman, H., and Shalaby, A.: The Impact of El Nino and La Nina on the United Arab Emirates (UAE) Rainfall, Gen. Sci. Res., 4, 5-10, https://doi.org/10.21828/gsr-04-01-002, 2016.

Almazroui, M.: Temperature Variability over Saudi Arabia and its Association with Global Climate Indices, JKAU Met, Env. Arid L. Agric. Sci, 23, 85-108, https://doi.org/10.4197/Met, 2012.

Anthes, R. A.: Enhancement of Convective Precipitation by Mesoscale Variations in Vegetative Covering in Semiarid Regions, J. Clim. Appl. Meteorol., 23, 541-554, https://doi.org/10.1175/15200450(1984)023<0541:EOCPBM>2.0.CO;2, 1984.

Balsamo, G., Beljaars, A., Scipal, K., Viterbo, P., van den Hurk, B., Hirschi, M., and Betts, A. K.: A Revised Hydrology for the ECMWF Model: Verification from Field Site to Terrestrial Water Storage and Impact in the Integrated Forecast System, J. Hydrometeorol., 10, 623-643, https://doi.org/10.1175/2008JHM1068.1, 2009.

Bauer, H. S., Weusthoff, T., Dorninger, M., Wulfmeyer, V., Schwitalla, T., Gorgas, T., Arpagaus, M., and Warrach-Sagi, K.: Predictive skill of a subset of models participating in D-PHASE in the COPS region, Q. J. Roy. Meteor. Soc., 137, 287-305, https://doi.org/10.1002/qj.715, 2011.

Bauer, H.-S., Schwitalla, T., Wulfmeyer, V., Bakhshaii, A., Ehret, U., Neuper, M., and Caumont, O.: Quantitative precipitation estimation based on high-resolution numerical weather prediction and data assimilation with WRF - a performance test, Tellus A, 67, 25047, https://doi.org/10.3402/tellusa.v67.25047, 2015.

Becker, K., Wulfmeyer, V., Berger, T., Gebel, J., and Münch, W.: Carbon farming in hot, dry coastal areas: an option for climate change mitigation, Earth Syst. Dynam., 4, 237-251, https://doi.org/10.5194/esd-4-237-2013, 2013.

Böer, B.: An introduction to the climate of the United Arab Emirates, J. Arid Environ., 35, 3-16, https://doi.org/10.1006/jare.1996.0162, 1997.

Branch, O. and Wulfmeyer, V.: Deliberate enhancement of rainfall using desert plantations, P. Natl. Acad. Sci. USA, 116, 1884118847, https://doi.org/10.1073/pnas.1904754116, 2019.

Branch, O., Warrach-Sagi, K., Wulfmeyer, V., and Cohen, S.: Simulation of semi-arid biomass plantations and irrigation using the WRF-NOAH model - a comparison with observations from Israel, Hydrol. Earth Syst. Sci., 18, 1761-1783, https://doi.org/10.5194/hess-18-1761-2014, 2014.

Branch, O., Behrendt, A., Gong, Z., Schwitalla, T., and Wulfmeyer, V.: Convection Initiation over the East- 
ern Arabian Peninsula, Meteorol. Z., 29, 67-77, https://doi.org/10.1127/METZ/2019/0997, 2020a.

Branch, O., Wulfmeyer, V., Schwitalla, T., Temimi, M., Fonseca, R., Nelli, N., and Milovac, J.: Scripts for publication "Seasonal and diurnal performance of daily forecasts with WRF-NOAHMP over the United Arab Emirates", Zenodo, https://doi.org/10.5281/zenodo.3894491, 2020b.

Branch, O., Wulfmeyer, V., Schwitalla, T., Temimi, M., Fonseca, R., Nelli, N., and Milovac, J.: Verification datasets for publication "Seasonal and diurnal performance of daily forecasts with WRFNOAHMP over the United Arab Emirates" [Data set], Zenodo, https://doi.org/10.5281/zenodo.3894544, 2020c.

Branch, O., Temimi, M., Schwitalla, T., Fonseca, R., Nelli, N., Weston, M., and Wulfmeyer, V.: MET tools statistics dataset used for publication "Seasonal and diurnal performance of daily forecasts with WRF-NOAHMP over the United Arab Emirates" [Data set], Zenodo, https://doi.org/10.5281/zenodo.4004195, 2020d.

Brown, B., Jensen, T., Gotway, J. H., Bullock, R., Gilleland, E., Fowler, T., Newman, K., Adriaansen, D., Blank, L., Burek, T., Harrold, M., Hertneky, T., Kalb, C., Kucera, P., Nance, L., Opatz, J., Vigh, J., and Wolff, J.: The Model Evaluation Tools (MET): More than a decade of community-supported forecast verification, B. Am. Meteorol. Soc., 1-68, https://doi.org/10.1175/bamsd-19-0093.1, 2020.

Bruintjes, R. and Yates, D.: Report on review and assessment of the potential for cloud seeding to enhance rain- fall in the Sultanate of Oman - NCAR, Boulder, Colorado, USA, 2003.

Chandran, A., Basha, G., and Ouarda, T. B. M. J.: Influence of climate oscillations on temperature and precipitation over the United Arab Emirates, Int. J. Climatol., 36, 225-235, https://doi.org/10.1002/joc.4339, 2016.

Chaouch, N., Temimi, M., Weston, M., and Ghedira, H.: Sensitivity of the meteorological model WRF-ARW to planetary boundary layer schemes during fog conditions in a coastal arid region, Atmos. Res., 187, 106-127, https://doi.org/10.1016/j.atmosres.2016.12.009, 2017.

Chowdhury, R., Mohamed, M. M. A., and Murad, A.: ScienceDirect Variability of Extreme Hydro-Climate Parameters in the NorthEastern Region of United Arab Emirates, Procedia Eng., 154, 639-644, https://doi.org/10.1016/j.proeng.2016.07.563, 2016.

Coppola, E., Sobolowski, S., Pichelli, E., Raffaele, F., Ahrens, B., Anders, I., Ban, N., Bastin, S., Belda, M., Belusic, D., CaldasAlvarez, A., Cardoso, R. M., Davolio, S., Dobler, A., Fernandez, J., Fita, L., Fumiere, Q., Giorgi, F., Goergen, K., Güttler, I., Halenka, T., Heinzeller, D., Hodnebrog, Jacob, D., Kartsios, S., Katragkou, E., Kendon, E., Khodayar, S., Kunstmann, H., Knist, S., Lavín-Gullón, A., Lind, P., Lorenz, T., Maraun, D., Marelle, L., van Meijgaard, E., Milovac, J., Myhre, G., Panitz, H. J., Piazza, M., Raffa, M., Raub, T., Rockel, B., Schär, C., Sieck, K., Soares, P. M. M., Somot, S., Srnec, L., Stocchi, P., Tölle, M. H., Truhetz, H., Vautard, R., de Vries, H., and Warrach-Sagi, K.: A first-of-its-kind multi-model convection permitting ensemble for investigating convective phenomena over Europe and the Mediterranean, Clim. Dynam., 55, 3-34, https://doi.org/10.1007/s00382-018-4521-8, 2020.

Danielson, J. J. and Gesch, D. B.: Global Multi-resolution Terrain Elevation Data 2010 (GMTED2010), available at: http://eros.usgs.gov/\#/Find_Data/Products_and_Data_ Available/GMTED2010 (last access: 18 May 2020), 2011.
Donlon, C. J., Martin, M., Stark, J., Roberts-Jones, J., Fiedler, E., and Wimmer, W.: The Operational Sea Surface Temperature and Sea Ice Analysis (OSTIA) system, Remote Sens. Environ., 116, 140-158, https://doi.org/10.1016/j.rse.2010.10.017, 2012.

Eager, R. E., Raman, S., Wootten, A., Westphal, D. L., Reid, J. S., and Mandoos, A. Al: A climatological study of the sea and land breezes in the Arabian Gulf region, J. Geophys. Res.-Atmos., 113, 1-12, https://doi.org/10.1029/2007JD009710, 2008.

Esri: ArcGIS V10.5 software, available at: https://www.esri. com/en-us/arcgis/products/arcgis-desktop/overview, last access: 15 March 2021.

Fekih, A. and Mohamed, A.: Evaluation of the WRF model on simulating the vertical structure and diurnal cycle of the atmospheric boundary layer over Bordj Badji Mokhtar (southwestern Algeria), J. King Saud Univ.-Sci., 31, 602-611, https://doi.org/10.1016/j.jksus.2017.12.004, 2017.

Feng, S., Hu, Q., Huang, W., Ho, C. H., Li, R. and Tang, Z.: Projected climate regime shift under future global warming from multi-model, multi-scenario CMIP5 simulations, Global Planet. Change, 112, 41-52, https://doi.org/10.1016/j.gloplacha.2013.11.002, 2014.

Figueroa-Espinoza, B., Salles, P., and Zavala-Hidalgo, J.: On the wind power potential in the northwest of the Yucatan Peninsula in Mexico, Atmosfera, 27, 77-89, https://doi.org/10.1016/S01876236(14)71102-6, 2014.

Foken, T.: 50 years of the Monin-Obukhov similarity theory, Bound.-Lay. Meteorol., 119, 431-447, https://doi.org/10.1007/s10546-006-9048-6, 2006.

Fonseca, R., Temimi, M., Thota, M. S., Nelli, N. R., Weston, M. J., Suzuki, K., Uchida, J., Kumar, K. N., Branch, O., Wehbe, Y., Al Hosari, T., Al Shamsi, N., and Shalaby, A.: On the Analysis of the Performance of WRF and NICAM in a Hyperarid Environment, Weather Forecast., 35, 891-919, https://doi.org/10.1175/waf-d19-0210.1, 2020.

Gutowski Jr., W. J., Giorgi, F., Timbal, B., Frigon, A., Jacob, D., Kang, H.-S., Raghavan, K., Lee, B., Lennard, C., Nikulin, G., O'Rourke, E., Rixen, M., Solman, S., Stephenson, T., and Tangang, F.: WCRP COordinated Regional Downscaling EXperiment (CORDEX): a diagnostic MIP for CMIP6, Geosci. Model Dev., 9, 4087-4095, https://doi.org/10.5194/gmd-9-4087-2016, 2016.

Hahmann, A. N., Vincent, C. L., Peña, A., Lange, J., and Hasager, C. B.: Wind climate estimation using WRF model output: method and model sensitivities over the sea, Int. J. Climatol., 35, 3422-3439, https://doi.org/10.1002/joc.4217, 2015.

Hong, S.-Y., Noh, Y., and Dudhia, J.: A New Vertical Diffusion Package with an Explicit Treatment of Entrainment Processes, Mon. Weather Rev., 134, 2318-2341, https://doi.org/10.1175/MWR3199.1, 2006.

Huang, J., Li, Y., Fu, C., Chen, F., Fu, Q., Dai, A., Shinoda, M., Ma, Z., Guo, W., Li, Z., Zhang, L., Liu, Y., Yu, H., He, Y., Xie, Y., Guan, X., Ji, M., Lin, L., Wang, S., Yan, H., and Wang, G.: Dryland climate change: Recent progress and challenges, Rev. Geophys., 55, 719-778, https://doi.org/10.1002/2016RG000550, 2017.

Iacono, M. J., Delamere, J. S., Mlawer, E. J., Shephard, M. W., Clough, S. A., and Collins, W. D.: Radiative forcing by long-lived greenhouse gases: Calculations with the AER ra- 
diative transfer models, J. Geophys. Res.-Atmos., 113, 1-8, https://doi.org/10.1029/2008JD009944, 2008.

Inness, A., Baier, F., Benedetti, A., Bouarar, I., Chabrillat, S., Clark, H., Clerbaux, C., Coheur, P., Engelen, R. J., Errera, Q., Flemming, J., George, M., Granier, C., Hadji-Lazaro, J., Huijnen, V., Hurtmans, D., Jones, L., Kaiser, J. W., Kapsomenakis, J., Lefever, K., Leitão, J., Razinger, M., Richter, A., Schultz, M. G., Simmons, A. J., Suttie, M., Stein, O., Thépaut, J.-N., Thouret, V., Vrekoussis, M., Zerefos, C., and the MACC team: The MACC reanalysis: an $8 \mathrm{yr}$ data set of atmospheric composition, Atmos. Chem. Phys., 13, 4073-4109, https://doi.org/10.5194/acp13-4073-2013, 2013.

Jacob, D., Teichmann, C., Sobolowski, S., Katragkou, E., Anders, I., Belda, M., Benestad, R., Boberg, F., Buonomo, E., Cardoso, R. M., Casanueva, A., Christensen, O. B., Christensen, J. H., Coppola, E., De Cruz, L., Davin, E. L., Dobler, A., Domínguez, M., Fealy, R., Fernandez, J., Gaertner, M. A., García-Díez, M., Giorgi, F., Gobiet, A., Goergen, K., Gómez-Navarro, J. J., Alemán, J. J. G., Gutiérrez, C., Gutiérrez, J. M., Güttler, I., Haensler, A., Halenka, T., Jerez, S., Jiménez-Guerrero, P., Jones, R. G., Keuler, K., Kjellström, E., Knist, S., Kotlarski, S., Maraun, D., van Meijgaard, E., Mercogliano, P., Montávez, J. P., Navarra, A., Nikulin, G., de Noblet-Ducoudré, N., Panitz, H. J., Pfeifer, S., Piazza, M., Pichelli, E., Pietikäinen, J. P., Prein, A. F., Preuschmann, S., Rechid, D., Rockel, B., Romera, R., Sánchez, E., Sieck, K., Soares, P. M. M., Somot, S., Srnec, L., Sørland, S. L., Termonia, P., Truhetz, H., Vautard, R., Warrach-Sagi, K., and Wulfmeyer, V.: Regional climate downscaling over Europe: perspectives from the EURO-CORDEX community, Reg. Environ. Chang., 20, 1-20, https://doi.org/10.1007/s10113-020-01606-9, 2020.

Jiménez, P. A., Dudhia, J., González-Rouco, J. F., Navarro, J., Montávez, J. P., and García-Bustamante, E.: A Revised Scheme for the WRF Surface Layer Formulation, Mon. Weather Rev., 140, 898-918, https://doi.org/10.1175/MWR-D-11-00056.1, 2012.

Karagulian, F., Temimi, M., Ghebreyesus, D., Weston, M., Kondapalli, N. K., Valappil, V. K., Aldababesh, A., Lyapustin, A., Chaouch, N., Al Hammadi, F. and Al Abdooli, A.: Analysis of a severe dust storm and its impact on air quality conditions using WRF-Chem modeling, satellite imagery, and ground observations, Air Qual. Atmos. Heal., 12, 453-470, https://doi.org/10.1007/s11869-019-00674-z, 2019.

Koster, R. D., Guo, Z., Dirmeyer, P. A., Bonan, G., Chan, E., Cox, P., Davies, H., Gordon, C. T., Kanae, S., Kowalczyk, E., Lawrence, D., Liu, P., Malyshev, S., Mcavaney, B., Mitchell, K., Mocko, D., Oki, T., Oleson, K. W., Pitman, A., Sud, Y. C., Taylor, C. M., Verseghy, D., Vasic, R., Xue, Y. and Yamada, T.: GLACE: The Global Land-Atmosphere Coupling Experiment. Part I: Overview, J. Hydrometeorol., 7, 590-610, https://doi.org/10.1175/JHM510.1, 2006.

Lelieveld, J., Proestos, Y., Hadjinicolaou, P., Tanarhte, M., Tyrlis, E., and Zittis, G.: Strongly increasing heat extremes in the Middle East and North Africa (MENA) in the 21st century, Climatic Change, 137, 245-260, https://doi.org/10.1007/s10584016-1665-6, 2016.

L'Heureux, M. L., Takahashi, K., Watkins, A. B., Barnston, A. G., Becker, E. J., Di Liberto, T. E., Gamble, F., Gottschalck, J., Halpert, M. S., Huang, B., Mosquera-Vásquez, K., and Wittenberg, A. T.: Observing and Predicting the
2015/16 El Niño, B. Am. Meteorol. Soc., 98, 1363-1382, https://doi.org/10.1175/BAMS-D-16-0009.1, 2017.

Lo, J. C.-F., Yang, Z.-L., and Pielke, R. A.: Assessment of three dynamical climate downscaling methods using the Weather Research and Forecasting (WRF) model, J. Geophys. Res., 113, D09112, https://doi.org/10.1029/2007jd009216, 2008.

Lu, J., Vecchi, G. A., and Reichler, T.: Expansion of the Hadley cell under global warming, Geophys. Res. Lett., 34, L06805, https://doi.org/10.1029/2006GL028443, 2007.

Mahmood, R., Pielke, R. A., Hubbard, K. G., Niyogi, D., Dirmeyer, P. A., Mcalpine, C., Carleton, A. M., Hale, R., Gameda, S., Beltrán-Przekurat, A., Baker, B., Mcnider, R., Legates, D. R., Shepherd, M., Du, J., Blanken, P. D., Frauenfeld, O. W., Nair, U. S., and Fall, S.: Land cover changes and their biogeophysical effects on climate, Int. J. Climatol., 34, 929-953, https://doi.org/10.1002/joc.3736, 2014.

Milovac, J., Warrach-Sagi, K., Behrendt, A., Späth, F., Ingwersen, J., and Wulfmeyer, V.: Investigation of PBL schemes combining the WRF model simulations with scanning water vapor differential absorption lidar measurements, J. Geophys. Res.-Atmos., 121, 624-649, https://doi.org/10.1002/2015JD023927, 2016.

Milovac, J., Ingwersen, J., and Warrach-Sagi, K.: Global top soil texture data compatible with the WRF model based on the Harmonized World Soil Database (HWSD) at 30 arc-second horizontal resolution Version 1.21, available at: https://cera-www.dkrz.de/WDCC/ui/cerasearch/entry? acronym=WRF_NOAH_HWSD_world_TOP_ST_v121 (last access: 15 August 2021), 2018.

Mlawer, E. J., Taubman, S. J., Brown, P. D., Iacono, M. J., and Clough, S. A.: Radiative transfer for inhomogeneous atmospheres: RRTM, a validated correlated-k model for the longwave, J. Geophys. Res.-Atmos., 102, 16663-16682, https://doi.org/10.1029/97jd00237, 1997.

Moody, E. G., King, M. D., Platnick, S., Schaaf, C. B., and Gao, F.: Spatially complete global spectral surface albedos: Value-added datasets derived from terra MODIS land products, IEEE T. Geosci. Remote Sens., 43, 144-157, https://doi.org/10.1109/TGRS.2004.838359, 2005.

Nakanishi, M. and Niino, H.: An improved Mellor-Yamada Level-3 model: Its numerical stability and application to a regional prediction of advection fog, Bound.-Lay. Meteorol., 119, 397-407, https://doi.org/10.1007/s10546-005-9030-8, 2006.

Nelli, N. R., Temimi, M., Fonseca, R. M., Weston, M. J., Thota, M. S., Valappil, V. K., Branch, O., Wulfmeyer, V., Wehbe, Y., Al Hosary, T., Shalaby, A., Al Shamsi, N., and Al Naqbi, H.: Impact of Roughness Length on WRF Simulated LandAtmosphere Interactions Over a Hyper-Arid Region, Earth Sp. Sci., 7, e2020EA001165, https://doi.org/10.1029/2020ea001165, 2020a.

Nelli, N. R., Temimi, M., Fonseca, R. M., Weston, M. J., Thota, M. S., Valappil, V. K., Branch, O., Wizemann, H. D., Wulfmeyer, V., and Wehbe, Y.: Micrometeorological measurements in an arid environment: Diurnal characteristics and surface energy balance closure, Atmos. Res., 234, 104745, https://doi.org/10.1016/j.atmosres.2019.104745, 2020 b.

Nielson, J., Ebba, D., Hahmann, A. N. and Boegh, E.: Representing vegetation processes in hydrometeorological simulations using the WRF mode, available at: https://orbit.dtu.dk/files/69208136/ JoakimRefslundThesis.pdf (last access: 15 March 2021), 2013. 
Niu, G.-Y.: The community Noah land surface model (LSM) with Multi-physics options, USer Guide, Heritage, 1-21, 2011.

Niu, G. Y., Yang, Z. L., Mitchell, K. E., Chen, F., Ek, M. B., Barlage, M., Kumar, A., Manning, K., Niyogi, D., Rosero, E., Tewari, M., and Xia, Y.: The community Noah land surface model with multiparameterization options (Noah-MP): 1. Model description and evaluation with local-scale measurements, J. Geophys. Res.-Atmos., 116, 1-19, https://doi.org/10.1029/2010JD015139, 2011.

OriginLab Corporation: Originlab, Origin(Pro), Version 9.7.0.185, Northampton, MA, USA available at: https://www.originlab.com/index.aspx?go=Products/Origin, last access: 15 March 2021.

Pielkel, R. and Avissar, R.: Influence of landscape structure on local and regional climate, Landsc. Ecol., 4, 133-155, https://doi.org/10.1007/BF00132857, 1990.

Powers, J. G., Klemp, J. B., Skamarock, W. C., Davis, C. A., Dudhia, J., Gill, D. O., Coen, J. L., Gochis, D. J., Ahmadov, R., Peckham, S. E., Grell, G. A., Michalakes, J., Trahan, S., Benjamin, S. G., Alexander, C. R., Dimego, G. J., Wang, W., Schwartz, C. S., Romine, G. S., Liu, Z., Snyder, C., Chen, F., Barlage, M. J., Yu, W., and Duda, M. G.: The weather research and forecasting model: Overview, system efforts, and future directions, B. Am. Meteorol. Soc., 98, 1717-1737, https://doi.org/10.1175/BAMSD-15-00308.1, 2017.

Prein, A. F. and Gobiet, A.: Impacts of uncertainties in European gridded precipitation observations on regional climate analysis, Int. J. Climatol., 37, 305-327, https://doi.org/10.1002/joc.4706, 2017.

Prein, A. F., Langhans, W., Fosser, G., Ferrone, A., Ban, N., Goergen, K., Keller, M., Tölle, M., Gutjahr, O., Feser, F., Brisson, E., Kollet, S., Schmidli, J., Van Lipzig, N. P. M., and Leung, R.: A review on regional convection-permitting climate modeling: Demonstrations, prospects, and challenges, Rev. Geophys., 53, 323-361, https://doi.org/10.1002/2014RG000475, 2015.

Quan, J., Di, Z., Duan, Q., Gong, W., Wang, C., Gan, Y., Ye, A., and Miao, C.: An evaluation of parametric sensitivities of different meteorological variables simulated by the WRF model, Q. J. Roy. Meteor. Soc., 142, 2925-2934, https://doi.org/10.1002/qj.2885, 2016.

Schwitalla, T., Bauer, H. S., Wulfmeyer, V., and Aoshima, F.: Highresolution simulation over central Europe: Assimilation experiments during COPS IOP 9c, Q. J. Roy. Meteor. Soc., 137, 156175, https://doi.org/10.1002/qj.721, 2011.

Schwitalla, T., Bauer, H.-S., Wulfmeyer, V., and Warrach-Sagi, K.: Continuous high-resolution midlatitude-belt simulations for July-August 2013 with WRF, Geosci. Model Dev., 10, 20312055, https://doi.org/10.5194/gmd-10-2031-2017, 2017.

Schwitalla, T., Branch, O., and Wulfmeyer, V.: Sensitivity study of the planetary boundary layer and microphysical schemes to the initialization of convection over the Arabian Peninsula, Q. J. Roy. Meteor. Soc., 146, 846-869, https://doi.org/10.1002/qj.3711, 2020.

Sherif, M., Almulla, M., Shetty, A., and Chowdhury, R. K.: Analysis of rainfall, PMP and drought in the United Arab Emirates, Int. J. Climatol., 34, 1318-1328, https://doi.org/10.1002/joc.3768, 2014.

Shimada, S., Ohsawa, T., Chikaoka, S., and Kozai, K.: Accuracy of the wind speed profile in the lower PBL as simu- lated by the WRF model, Sci. Online Lett. Atmos., 7, 109-112, https://doi.org/10.2151/sola.2011-028, 2011.

Skamarock, W. C., Klemp, J. B., Dudhia, J., Gill, D. O., Barker, D. M., Duda, M. G., Huang, X.-Y., Wang, W., and Powers, J. G.: A Description of the Advanced Research WRF Version 3, https://doi.org/10.5065/D68S4MV, 2008.

Smith, V. H., Mobbs, S. D., Burton, R. R., Hobby, M., Aoshima, F., Wulfmeyer, V., and Di Girolamo, P.: The role of orography in the regeneration of convection: A case study from the convective and orographically-induced precipitation study, Meteorol. Z., 24, 83-97, https://doi.org/10.1127/metz/2014/0418, 2014.

Sørland, S. L., Schär, C., Lüthi, D., and Kjellström, E.: Bias patterns and climate change signals in GCM-RCM model chains, Environ. Res. Lett., 13, 074017, https://doi.org/10.1088/17489326/aacc77, 2018.

Steinhoff, D. F., Bruintjes, R., Hackera, J., Keller, T., Williams, C., Jensen, T., Al Mandous, A., and Al Yazeedi, O. A.: Influences of the monsoon trough and Arabian heat low on summer rainfall over the United Arab Emirates, Mon. Weather Rev., 146, 13831403, https://doi.org/10.1175/MWR-D-17-0296.1, 2018.

The NCAR Command Language (Version 6.6.2): Software, Boulder, Colorado, UCAR/NCAR/CISL/TDD, https://doi.org/10.5065/D6WD3XH5, 2019.

Thompson, G. and Eidhammer, T.: A Study of Aerosol Impacts on Clouds and Precipitation Development in a Large Winter Cyclone, J. Atmos. Sci., 71, 3636-3658, https://doi.org/10.1175/JAS-D-13-0305.1, 2014.

Valappil, V. K., Temimi, M., Weston, M., Fonseca, R., Nelli, N. R., Thota, M., and Kumar, K. N.: Assessing Bias Correction Methods in Support of Operational Weather Forecast in Arid Environment, Asia-Pacific J. Atmos. Sci., 56, 333-347, https://doi.org/10.1007/s13143-019-00139-4, 2020.

Warrach-Sagi, K., Schwitalla, T., Wulfmeyer, V., and Bauer, H. S.: Evaluation of a climate simulation in Europe based on the WRFNOAH model system: Precipitation in Germany, Clim. Dynam., 41, 755-774, https://doi.org/10.1007/s00382-013-1727-7, 2013.

Wehbe, Y., Temimi, M., Weston, M., Chaouch, N., Branch, O., Schwitalla, T., Wulfmeyer, V., Zhan, X., Liu, J., and Al Mandous, A.: Analysis of an extreme weather event in a hyper-arid region using WRF-Hydro coupling, station, and satellite data, Nat. Hazards Earth Syst. Sci., 19, 1129-1149, https://doi.org/10.5194/nhess-19-1129-2019, 2019.

Weston, M., Chaouch, N., Valappil, V., Temimi, M., Ek, M., and Zheng, W.: Assessment of the Sensitivity to the Thermal Roughness Length in Noah and Noah-MP Land Surface Model Using WRF in an Arid Region, Pure Appl. Geophys., 176, 2121-2137, https://doi.org/10.1007/s00024-018-1901-2, 2019.

Wood, L. A.: The use of dew-point temperature in humidity calculations, J. Res. Natl. Bur. Stand. Sect. C Eng. Instrum., 74C, 117, https://doi.org/10.6028/jres.074c.014, 1970.

Wulfmeyer, V., Branch, O., Warrach-Sagi, K., Bauer, H. S., Schwitalla, T., and Becker, K.: The impact of plantations on weather and climate in coastal desert regions, J. Appl. Meteorol. Climatol., 53, 1143-1169, https://doi.org/10.1175/JAMC-D-130208.1, 2014.

Wulfmeyer, V., Turner, D. D., Baker, B., Banta, R., Behrendt, A., Bonin, T., Brewer, W. A., Buban, M., Choukulkar, A., Dumas, R., Hardesty, R. M., Heus, T., Ingwersen, J., Lange, D., Lee, T. R., Metzendorf, S., Muppa, S. K., Meyers, T., Newsom, R., Os- 
man, M., Raasch, S., Santanello, J., Senff, C., SpäTh, F., Wagner, T., and Weckwerth, T.: A new research approach for observing and characterizing land?atmosphere feedback, B. Am. Meteorol. Soc., 99, 1639-1667, https://doi.org/10.1175/BAMS-D-170009.1, 2018.

Yang, B., Qian, Y., Berg, L. K., Ma, P. L., Wharton, S., Bulaevskaya, V., Yan, H., Hou, Z., and Shaw, W. J.: Sensitivity of Turbine-Height Wind Speeds to Parameters in Planetary Boundary-Layer and Surface-Layer Schemes in the Weather Research and Forecasting Model, Bound.-Lay. Meteorol., 162, 117142, https://doi.org/10.1007/s10546-016-0185-2, 2017.

Yousef, L. A., Temimi, M., Wehbe, Y., and Al Mandous, A.: Total cloud cover climatology over the United Arab Emirates, Atmos. Sci. Lett., 20, e883, https://doi.org/10.1002/asl.883, 2019.
Zhang, H., Pu, Z., and Zhang, X.: Examination of Errors in NearSurface Temperature and Wind from WRF Numerical Simulations in Regions of Complex Terrain, Weather Forecast., 28, 893914, https://doi.org/10.1175/WAF-D-12-00109.1, 2013.

Zhao, C., Gong, J., Wang, H., Wei, S., Song, Q., and Zhou, Y.: Changes of temperature and precipitation extremes in a typical arid and semiarid zone: Observations and multimodel ensemble projections, Int. J. Climatol., 40, 5128-5153, https://doi.org/10.1002/joc.6510, 2020. 